\title{
Important genetic checkpoints for insulin resistance in salt-sensitive (S) Dahl rats Marlene F Shehata
}

Address: Department of Cellular and Molecular Medicine, University of Ottawa Heart Institute, K1Y 4W7, Ottawa, ON, Canada Email: Marlene F Shehata - mshehata@ottawaheart.ca

Published: 21 June 2008

Cardiovascular Diabetology 2008, 7:19 doi:10.1 /86/1475-2840-7-19

This article is available from: http://www.cardiab.com/content/7///I

2008 Shehata; licensee BioMed Central Ltd.

This is an Open Access article distributed under the terms of the Creative Commons Attribution License (http://creativecommons.org/licenses/by/2.0), which permits unrestricted use, distribution, and reproduction in any medium, provided the original work is properly cited.

\begin{abstract}
Despite the marked advances in research on insulin resistance (IR) in humans and animal models of insulin resistance, the mechanisms underlying high salt-induced insulin resistance remain unclear. Insulin resistance is a multifactorial disease with both genetic and environmental factors (such as high salt) involved in its pathogenesis. High salt triggers insulin resistance in genetically susceptible patients and animal models of insulin resistance. One of the mechanisms by which high salt might precipitate insulin resistance is through its ability to enhance an oxidative stress-induced inflammatory response that disrupts the insulin signaling pathway. The aim of this hypothesis is to discuss two complementary approaches to find out how high salt might interact with genetic defects along the insulin signaling and inflammatory pathways to predispose to insulin resistance in a genetically susceptible model of insulin resistance. The first approach will consist of examining variations in genes involved in the insulin signaling pathway in the Dahl $S$ rat (an animal model of insulin resistance and salt-sensitivity) and the Dahl R rat (an animal model of insulin sensitivity and salt-resistance), and the putative cellular mechanisms responsible for the development of insulin resistance. The second approach will consist of studying the over-expressed genes along the inflammatory pathway whose respective activation might be predictive of high salt-induced insulin resistance in Dahl S rats.
\end{abstract}

Variations in genes encoding the insulin receptor substrates -I and/or -2 (IRS-I, -2) and/or genes encoding the glucose transporter (GLUTs) proteins have been found in patients with insulin resistance. To better understand the combined contribution of excessive salt and genetic defects to the etiology of the disease, it is essential to investigate the following question:

Question I: Do variations in genes encoding the IRS - I and -2 and/or genes encoding the GLUTs proteins predict high salt-induced insulin resistance in Dahl $\mathrm{S}$ rats?

A significant amount of evidence suggested that salt-induced oxidative stress might predict an inflammatory response that upregulates mediators of inflammation such as the nuclear factorkappa B (NF-kappa B), the tumor necrosis factor-alpha (TNF- $\alpha$ ) and the c-Jun Terminal Kinase (JNK). These inflammatory mediators disrupt the insulin signaling pathway and predispose to insulin resistance. Therefore, the following question will be thoroughly investigated:

Question 2: Do variations in genes encoding the NF-kappa B, the TNF- $\alpha$ and the JNK, independently or in synergy, predict an enhanced inflammatory response and subsequent insulin resistance in Dahl $S$ rats in excessive salt environment? 
Finally, to better understand the combined role of these variations on glucose metabolism, the following question will be addressed:

Question 3: What are the functional consequences of gene variations on the rate of glucose delivery, the rate of glucose transport and the rate of glucose phosphorylation in Dahl S rats?

The general hypothesis is that "high-salt diet in combination with defects in candidate genes along the insulin signaling and inflammatory pathways predicts susceptibility to high salt-induced insulin resistance in Dahl S rats".

\section{Background Insulin Resistance}

Insulin resistance is defined as an impaired responsiveness to both endogenous and exogenous insulin resulting in high blood glucose levels and compensatory hyperinsulinemia [1]. Insulin resistance predicts a constellation of risk factors that increase the risk of cardiovascular diseases. These include high blood pressure, obesity, type 2 diabetes, elevated triglycerides, and lowered high density lipoprotein cholesterol (HDL-C) [2,3]. Statistics have shown that over $30 \%$ of Canadian adults have insulin resistance [4] and that about $50 \%$ of salt-sensitive subjects are insulin resistant [3]. The prevalence of the disease is expected to increase dramatically over the coming decades causing an enormous economic burden in both the developing and developed worlds.

Insulin resistance has major genetic and environmental factors (such as dietary salt) that are involved in its pathogenesis [1]. Despite the intense investigations into the mechanisms of insulin resistance, the contribution of high-salt to insulin resistance is not yet clear and the genes responsible for the development of high salt-induced insulin resistance remain in dispute. Because insulin resistance phenotype results from the cumulative effects of several contributing genetic alterations, I chose to focus on the genetic differences in candidate genes along the insulin signaling and inflammatory pathways.

Variations in major genes encoding the insulin receptor substrates - 1 and - 2 (IRS-1 and -2) and the glucose transporter (GLUTs) proteins correlate with insulin resistance in humans and animal models of insulin resistance. These variations act by different mechanisms to disrupt the insulin signaling pathway leading to defects in glucose transport and glucose metabolism.

Multiple lines of evidence suggest a putative role of saltinduced oxidative stress in the etiology of insulin resistance [5]. Salt-induced oxidative stress triggers a powerful inflammatory response that disrupts the insulin signaling pathway and might possibly explain insulin resistance in genetically susceptible populations [6-8]. Owing to the fact that high salt-fed Dahl $S$ rats have augmented salt- induced oxidative stress in most tissues [9-12], and that oxidative stress generates mediators of inflammation such as NF-kappa B, TNF- $\alpha$ and JNK, known to disrupt the insulin signaling pathway, I chose to review the putative genetic variations in the markedly over-expressed genes along the inflammatory pathway (NF-kappa B, TNF- $\alpha$ and JNK) that might be predictive of insulin resistance in Dahl $\mathrm{S}$ rat model. Because the promoter regions of some of the candidate genes proposed in the current study might possibly harbor sodium-binding sequences $[13,14]$, any sequence variations in these putative sodium response elements might predict protection against insulin resistance in Dahl $\mathrm{R}$ rats in excessive salt environments. The long-term goal is to establish a subset of single nucleotide polymorphisms (SNPs) that are predictive of insulin resistance in excessive salt environments.

\section{Why Dahl rats?}

Dahl inbred rat strains are classified into salt-sensitive (S) and salt-resistant $(\mathrm{R})$ based on their blood pressure responses to high salt diet. Dahl S and R rats share $80 \%$ of their genetic background [15]. Contrary to Dahl R, Dahl S rats represent a robust model of insulin-resistance syndrome on account of their insulin resistance, hypertriglyceridaemia, abdominal obesity and salt-sensitive hypertension that is exacerbated on dietary sodium intake [16-19]. Dahl S rats alone had significant insulin resistance, hyperinsulinemia, elevated systolic and diastolic blood pressures on high salt diet $(8 \% \mathrm{NaCl})$ for 4 weeks versus normal salt diet $[19,20]$. Whole body insulin resistance in Dahl S rats was evidenced by a decrease in glucose utilization during the hyperinsulinemia-euglycemic clamp analysis while peripheral insulin resistance in Dahl $S$ rats was evidenced by a decrease in insulin-stimulated 2 deoxy-glucose uptake by adipocytes and skeletal muscles obtained from high-salt-fed Dahl S versus Dahl R rats. At the molecular level, tyrosyl phosphorylation of the insulin receptor, insulin receptor substrates and PI $3 \mathrm{~K}$, as well as serine phosphorylation of Akt were all enhanced in Dahl S versus R rats [19].

Insulin resistance in Dahl S rats does not seem to develop as a result of an alteration in the insulin receptor number, affinity, binding parameters, mRNA levels or tissue distri- 
bution in liver, muscle and kidney tissues. These parameters were all comparable in Dahl S and R rats on high or low salt chow [20]. Moreover, the muscle and adipose tissue glucose transporter protein 4 (GLUT 4) expression was comparable in soleus muscle and adipose tissue of Dahl S and R rats on low and high salt diet [19]. Insulin resistance in Dahl S rats is worsened on high salt diet, and high salt diet enhances oxidative stress-induced inflammatory mediators such as TNF- $\alpha$, JNK, and NF-kappa B in Dahl S rats, therefore, high salt-induced oxidative stress might predict a powerful inflammatory response in Dahl $\mathrm{S}$ versus $\mathrm{R}$ rats. This powerful inflammatory response might be caused by genetic differences that enhances the expression of inflammatory mediators and predispose Dahl S rats to insulin resistance.

In conclusion, the lack of change in the insulin receptor number in combination with multiple changes in post receptor signaling suggests a post receptor defect. The decreased sensitivity to insulin in Dahl S rats may arise from a common variant (s) in genes along the insulin signaling and/or inflammatory pathways that triggers a powerful inflammatory response and enhance overt insulin resistance in Dahl $\mathrm{S}$ rats in excessive salt environment (Figure 1).

\section{Factors along the insulin signaling pathway with implications in insulin resistance}

Insulin receptor substrates -I and -2 (IRS-I and IRS-2)

Insulin effects are predominant in skeletal muscles, liver, kidney, fat and brain causing increased renal sodium retention, modulation of transmembrane cation transport, induction of growth promoting effects of vascular smooth muscle cells and vascular hyperreactivity [21]. Insulin actions are initiated when insulin binds to a highaffinity heterotetrameric transmembrane protein receptor that is present in all mammalian cells [22]. This is followed by activation of second messengers, also called docking proteins, such as the insulin receptor substrates$1,-2,-3$ and -4 , (IRS-1, -2, -3 and -4) [23-26] via a series of phosphorylation-dephosphorylation reactions that result in stimulation of glucose metabolism [27] (Figure 2 ). While IRS-3 and -4 play a role in cell growth and differentiation, IRS-1 and -2 play an important role in glucose metabolism and represent attractive candidate genes to study in insulin resistance (Tables 1 and 2).

In humans, associations between insulin resistance and common variants in IRS-1 and -2 have been reported in several populations [25,28-36], including obese Caucasian children, adults, Asian Indians, Mexicans and Europeans. Mechanisms underlying the contribution of IRS-1 and/or -2 variants to insulin resistance include [37] (Figure 3): i) altering IRS-1 and/or- 2 expression and function, ii) reduced IRS-1 and/or - 2 binding to the insulin recep- tor, iii) a defect in binding of IRS-1 and/or -2 variant (s) to the p85 regulatory subunit of the PI3-kinase and a decrease in PI3-kinase activity. This in turn leads to either a decreased GLUT4 translocation to the plasma membrane, further reducing glucose transport and glycogen synthesis, or a significant IRS-1 and/or -2 -induced decrease in phosphorylation of glycogen synthase kinase3 (GSK-3), an enzyme that is important in glycogen synthesis, thus causing reduced glycogen synthesis, iv) reduced IRS-1 content that is not compensated by a constitutive increase in the IRS-2 protein content. This result in a reduced insulin-stimulated PI3-kinase activity and a significant decrease in Akt phosphorylation and activity. Overall, IRS-1 and/or 2 variants seem to impair the ability of insulin to activate the IRS/PI3-kinase/Akt/GSK-3 signaling pathway leading to defects in glucose transport, glucose transporters translocation and glycogen synthesis.

IRS- 1 and - 2 proteins are subjected to phosphorylation on either tyrosine or serine residues (Figure 4 for structural organization). IRS-1 and - 2 phosphorylation on tyrosine residues activates IRS proteins to bind to signaling molecules containing SH2 domains, including PI3K $[24,38]$. Unlike tyrosyl phosphorylation, serine phosphorylation of IRS proteins attenuated insulin signaling and might potentially explain an additional mechanism of insulin resistance in rodents [39] (Figure 5). Owing to the fact that IRS proteins have three times the number of serine residues compared to the number of tyrosine residues, the significance of serine phosphorylation has been significantly highlighted. Serine phosphorylation of IRS-1 and IRS-2 is the main mechanism of suppressing insulin signaling [40,41] in the following ways [40-42]: 1) They can induce dissociation of IRS proteins from the insulin receptor, 2) hinder tyrosine phosphorylation sites and release IRS proteins from intracellular complexes that maintain them in close proximity to the receptor, 3 ) induce IRS protein degradation, or 4) turn IRS proteins into inhibitors of the insulin receptor kinase. Differential serine phosphorylation on IRS-1 and/or- 2 has not been studied in Dahl S versus $\mathrm{R}$ rats. Additionally, serine phosphorylation of the insulin receptor and IRS-1 and -2 [43] is enhanced by chronic hyperinsulinemia that negatively modulate insulin signaling via activation of TNF- $\alpha$ [43]. Therefore, chronic hyperinsulinemia in high-salt-fed-Dahl S rats [16] might as well enhance serine phosphorylation on IRS-1 and/or IRS-2 and explain insulin resistance in Dahl S rats.

\section{Glucose Transporters}

The ability to transport glucose across plasma membranes is mediated by members of the glucose transporter proteins (Table 3). Two families of glucose transporter have been identified: i) GLUTs: facilitated-diffusion glucose transporter family also known as 'uniporters,' (GLUT1 through GLUT4), ii) SGLTs: sodium-dependent glucose 


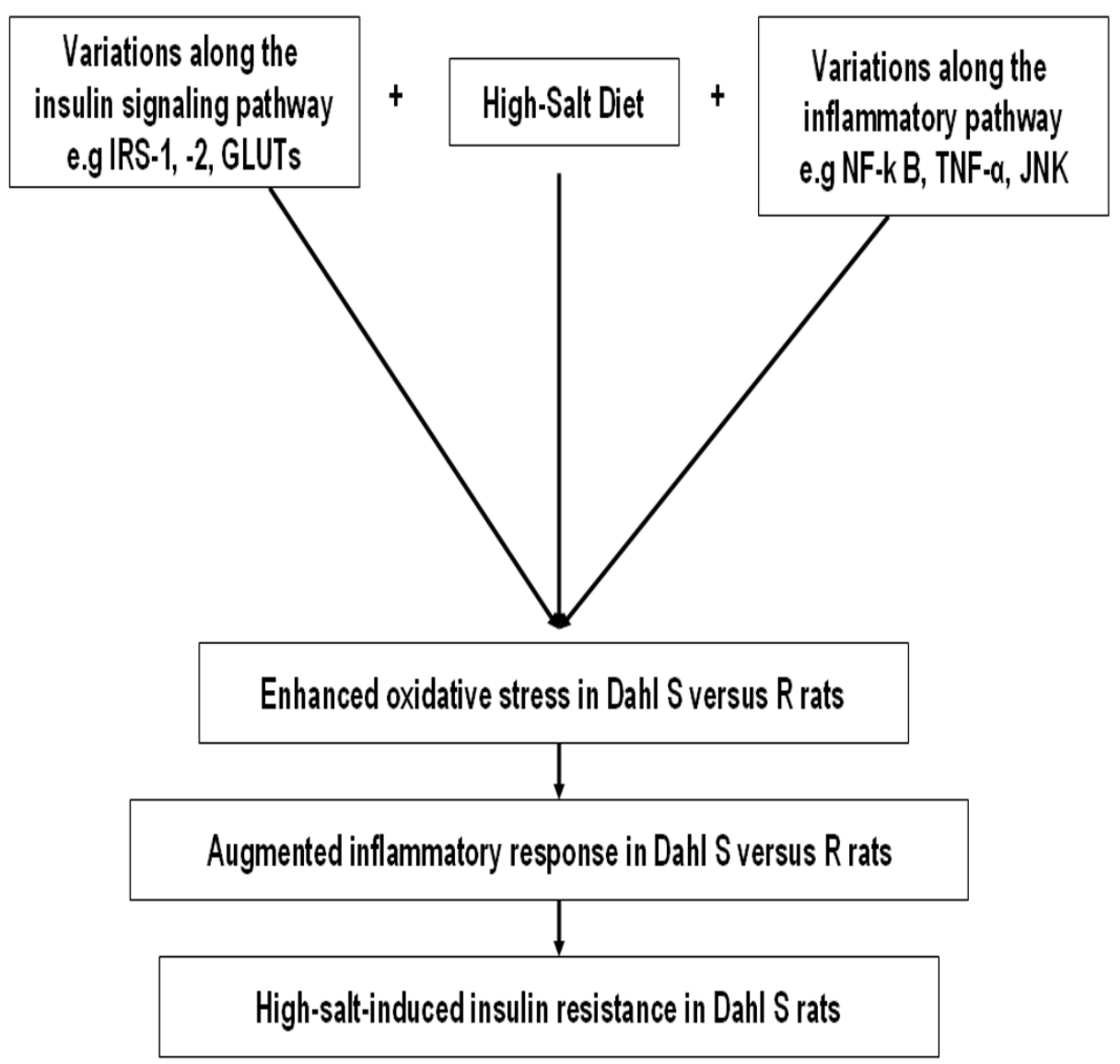

Figure I

Mechanism of High Salt-Induced Insulin Resistance in DahI S rats. Our proposed model of high salt-induced insulin resistance in Dahl S rats depends on the combined contributions of high salt and genetic defects along the insulin signaling and inflammatory pathways, which in turn predispose Dahl S rats to an augmented inflammatory response and overt insulin resistance.

transporter family, also known as 'cotransporters' or 'symporters', transport glucose against its concentration gradient.

In humans, 23, 38, 2, 1 and 41 mutations have been reported in GLUT 1, GLUT 2, GLUT 4, GLUT 10, and the SGLT 1, respectively. These mutations have been associated with glucose transporters deficiency, lower serum insulin levels, glucose malabsorption and NIDDM making them attractive molecular targets for insulin resistance and glucose abnormalities [44] (For review, the Human Gene Mutation Database).

In rats, at least 7 genes are involved in glucose transport. They are denoted by Slc2a1, Slc2a2, Slc2a3, Slc2a4, Slc2a8, Slc37a4, Naglt1 (Table 3). Despite the reported variations in some of the above genes in rats (Table 4), no further functional studies have been reported so far. Using the TRANSFAC ${ }^{\circledR}$ Computer program [45], sodium-binding sequences $[13,14]$ were identified in the promoters of Slc2a1, Slc2a2, and Slc2a4. As such, association between high salt and insulin resistance might be through the glucose transporter genes.

Factors along the inflammatory pathways

Inflammation causes a profound change in gene expression of a large number of inflammatory proteins such as tumor necrosis factor-alpha (TNF- $\alpha$ ), c-Jun Terminal Kinase (JNK) and nuclear factor-kappa B, (NF-kappa B) which increases oxygen consumption and produce many reactive oxygen species (ROS). ROS might as well be triggered by high salt [46]. ROS interfere with normal insulin signaling and precipitate insulin resistance via a number of mechanisms including: i) disruption of insulininduced IRS-1 and PI3-kinase phosphorylation and cellular distribution, ii) reduction in GLUT4 expression levels, or iii) reduction in GLUT4 translocation to the plasma membrane [47-50]. High salt-fed Dahl S rats had aug- 


\section{Insulin}
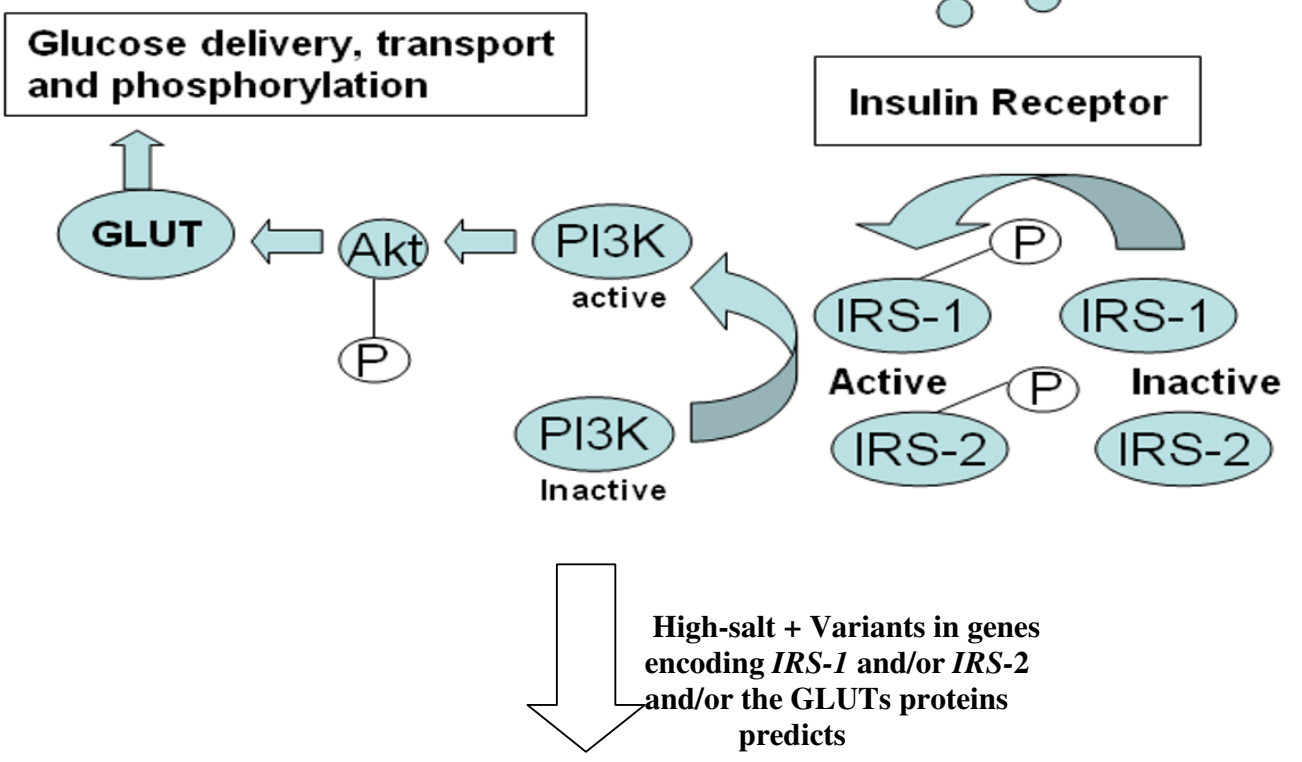

High Salt-Induced Insulin Resistance in Dahl S rats

\section{Figure 2}

Illustration of the Insulin Pathway and its Potential Contribution to High Salt-Induced Insulin Resistance in DahI S rats. When insulin activates the insulin receptor in vivo, tyrosine phosphorylation of the IRS-I and IRS-2 activates phosphoinositide 3 kinase (PI3K) enzyme, whose activation in turn stimulates the serine phosphorylation of Akt (Protein kinase B) [108]. The latter enzyme (PKB) stimulates glucose transport in muscle and adipose tissue through the stimulated translocation of glucose transporter GLUT4 isoform [109]. PKB also stimulates glycogen synthesis in the liver and muscle, and stimulates lipogenesis in adipose tissue. Existence of variants in genes encoding IRS-I and/or-2 and glucose transporter proteins might impair insulin signaling by suppressing the IRS-I and/or -2 mRNA levels, protein levels and activity or enhancing serine phosphorylation of IRS-I and -2 resulting in high salt-induced insulin resistance in Dahl S rats.

mented NADPH oxidase activity (oxidative stress inducer) in cardiac $[10]$, renal $[9,11,12]$, mesenteric microvascular [9] and brain tissues [51]. Even plasma levels of hydrogen peroxide (oxidative-stress inducer) in high-salt-fed Dahl S rats were significantly elevated [9], and the renal antioxidant, superoxide dismutase levels were diminished [9]. As such, high salt-induced oxidative stress might predict a powerful inflammatory response in Dahl $\mathrm{S}$ versus $\mathrm{R}$ rats because of genetic differences along the inflammatory pathway that predispose them to perturbations in the expression of inflammatory genes.

Table 5 includes a list of inflammatory genes (pro- and anti-inflammatory factors) with potential implications in insulin resistance. While there are a plethora of genes associated with inflammation and insulin resistance, I will focus on a select few TNF- $\alpha$, JNK, NF-kappa B which based on the literature are plausible candidates. TNF- $\alpha$ and JNK are potential mediators of insulin resistance and are significantly upregulated in high-salt-fed-Dahl S rats $[52,53]$. TNF- $\alpha$ and JNK contribute to insulin resistance by: i) promoting serine phosphorylation of IRS-1 and -2, ii) formation of a stable complex with IRS- 1 and/or IRS-2, iii) impairing the ability of IRS- 1 and -2 to associate with the insulin receptor and inhibiting insulin-stimulated tyrosine phosphorylation [54-57].

On the other hand, high salt-fed Dahl S rats possess high renal nuclear factor-kappa B, NF-kappa B [58], which might predispose them to insulin resistance. This is because inhibition of the nuclear factor I-kappa $\mathrm{B}$ kinase B (IKBKB), which is a member of the NF-kappa B, with salicylates or through targeted gene disruption causes a dramatic improvement of insulin sensitivity in animal models of insulin resistance such as ob/ob mice and obese Zucker fatty rats $[59,60]$. It also reversed hyperglycemia, 
Table I: Chromosomal location, genomic and protein sizes of IRS-I and IRS-2 in rats

\begin{tabular}{|c|c|c|c|c|}
\hline Gene & Location & Size & $\begin{array}{l}\text { Size of Coding } \\
\text { region }\end{array}$ & Justification \\
\hline $\begin{array}{l}\text { Insulin receptor } \\
\text { substrate I (IRS-I) }\end{array}$ & chr9:8| 58525 I-8|63807| & $\begin{array}{l}5365 \\
\text { bases }\end{array}$ & 3708 bases & $\begin{array}{l}\text { Low cellular IRS I gene and protein expression predict } \\
\text { insulin resistance and NIDDM. } \\
\text { Impairment of insulin-induced glucose uptake by skeletal } \\
\text { muscles from high-salt-fed Dahl S rats was neither due to } \\
\text { changes in the insulin receptor number, mRNA or binding } \\
\text { affinity, nor due to diminished expression of GLUT4 } \\
\text { protein. Impairment in the insulin signaling pathway might } \\
\text { possibly be downstream of the insulin receptor and } \\
\text { upstream of GLUT4, possibly in the IRS-I and/or IRS-2 } \\
\text { signaling molecules. }\end{array}$ \\
\hline $\begin{array}{l}\text { Insulin receptor } \\
\text { substrate } 2 \text { (IRS-2) }\end{array}$ & chr|6:|8878|39-1888944| & $\begin{array}{l}24234 \\
\text { bases }\end{array}$ & 3963 bases & $\begin{array}{l}\text { Ubiquitin-mediated degradation of IRSI and IRS2 promotes } \\
\text { insulin resistance. IRS2 dysfunction is critical in the } \\
\text { development of type } 2 \text { diabetes. Insulin was not able to } \\
\text { suppress gluconeogenic gene expression in primary } \\
\text { hepatocytes lacking IRS-2, but when IRS-2 signaling was } \\
\text { reconstituted, these cells recovered this response to } \\
\text { insulin. }\end{array}$ \\
\hline
\end{tabular}

Summary of IRS-I and -2 genes demonstrating their chromosomal location, respective genomic and coding sequence sizes, and known effects of their dysregulation.

hyperinsulinemia, and dyslipidemia in obese rodents. On the other hand, activation or overexpression of the nuclear factor I-kappa B (IKBKB) attenuated insulin signaling in cultured cells [60].

As such, common variant (s) in the TNF- $\alpha$, JNK, or NFkappa B might predict a powerful inflammatory reaction in response to high salt and might possibly explain insulin resistance in Dahl S rats.

\section{Factors implicated in glucose utilization by the cell}

Glucose utilization requires three steps: i) delivery of glucose to the plasma membrane, which depends on the organ's blood flow, capillary recruitment and endothelial permeability to glucose [61], ii) facilitated transport across the membrane, which mainly relies on the glucose transporters numbers and intrinsic activity [61] and iii) intracellular phosphorylation to glucose-6-phosphate by a hexokinase cytosolic enzyme (HK) (Figure 6) [62].

In most cases, glucose transport is believed to be the rate limiting step. However, in conditions of hyperinsulinemia like that seen in high-salt-fed Dahl S rats, the rate limiting step may switch to phosphorylation $[63,64]$.
Perturbations in any of these steps might precipitate the high salt-induced insulin resistance in Dahl S rats. Variations in the genes proposed in the current study might affect any of the three steps involved in glucose utilization. As for the hexokinase enzyme, increased adrenal content of norepinephrine and epinephrine in high-saltfed Dahl S versus R rats might contribute to a defective hexokinase enzymatic activity in Dahl S rats [65]. Epinephrine decreases glucose clearance in vivo upon insulin stimulation [66,67] and suppresses insulin-stimulated glucose uptake in skeletal muscles [68-70]. This is possibly by: i) stimulating glycogenolysis and accumulating glucose-6-phosphate $[68,71,72]$ (a strong inhibitor of the hexokinase enzyme) $[73,74]$; or ii) by reducing glucose transport across the membrane [75-77].

Despite comparable muscle and adipose tissue GLUT4 protein levels in Dahl S versus $\mathrm{R}$ rats on high and normal salt diet, Dahl $S$ rats showed reduced glucose uptake by the muscle [19]. Reduced glucose uptake in high salt-fedDahl S rats might be explained by the high salt-induced release of epinephrine and norepinephrine that directly and indirectly inhibit glucose phosphorylation and utilization. Moreover, high salt causes solubilization of the

Table 2: Previously identified variant (s) in IRS-I gene in rats

\begin{tabular}{cccccc}
\hline Gene & Strain & Type & Residue & SNP & Amino Acid \\
\hline IRS-I & $\begin{array}{c}\text { Sprague Dawley } \\
\text { Ref: Brown Norway }\end{array}$ & Non-synonymous & 1160 & ENSRNOSNP255223I & T/C \\
\hline
\end{tabular}

Table showing previously reported IRS-I variant in Sprague Dawley rats compared to Brown Norway rats. The IRS-I non-synonymous variant caused an amino acid change from Cysteine to Tyrosine. Functional assessment of such variant is yet to be determined [133]. 


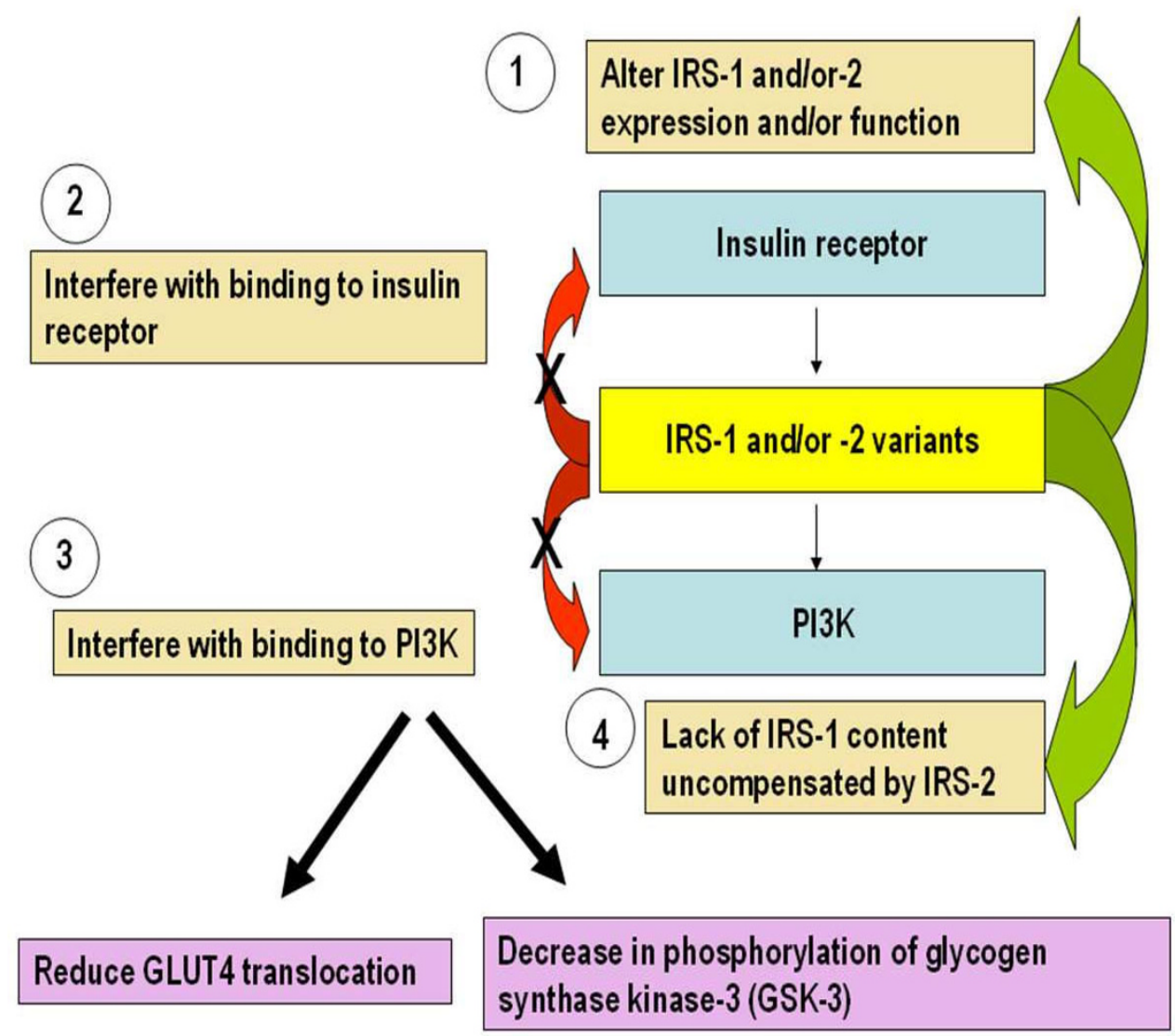

Figure 3

Contribution of IRS-I and/or-2 variants to Insulin Resistance. Mechanisms by which IRS-I and/or -2 variants contribute to insulin resistance include: I) altering IRS-I and/or-2 expression and function, 2) reduced IRS-I and/or -2 binding to the insulin receptor, 3) a defect in binding of IRS-I and/or -2 variant (s) to the p85 regulatory subunit of the PI3-kinase and a decrease in PI3-kinase activity. The latter leads to either a decreased GLUT4 translocation to the plasma membrane, further reducing glucose transport and glycogen synthesis, or a significant IRS-I and/or -2 -induced decrease in phosphorylation of glycogen synthase kinase-3 (GSK-3), an enzyme that is important in glycogen synthesis, thus causing reduced glycogen synthesis, 4) reduced IRS-I content that is not compensated by a constitutive increase in the IRS-2 protein content. This result in a reduced insulinstimulated PI3-kinase activity and a significant decrease in Akt phosphorylation and activity.

hexokinase and subsequent inhibition [78], which might be an additive mechanism in reducing glucose uptake by peripheral tissues in Dahl S rats. As such, high salt combined with genetic differences in Dahl S versus $\mathrm{R}$ rats might predispose them to insulin resistance.

\section{Hypothesis and objectives}

\section{General Hypothesis}

High salt diet combined with genetic differences along the insulin signaling and inflammatory pathways predict a powerful inflammatory response and susceptibility to high salt-induced insulin resistance in Dahl S rats.

\section{Specific Hypotheses}

Dahl S rats harbour common variant(s) in the genes encoding the insulin receptor substrates- 1 and/or- 2 and/ or the glucose transporter proteins.

Dahl S rats will display a more powerful inflammatory response to high salt-induced oxidative stress because of common variant(s) in the genes encoding the tumor necrosis factor-alpha, c-jun terminal kinase and the nuclear factor-kappa B.

Dahl rats will show reduced glucose delivery, transport and phosphorylation in liver and kidney tissues compared to Dahl R rats. These differences will be related to the combined effect of high salt diet and genetic differ- 


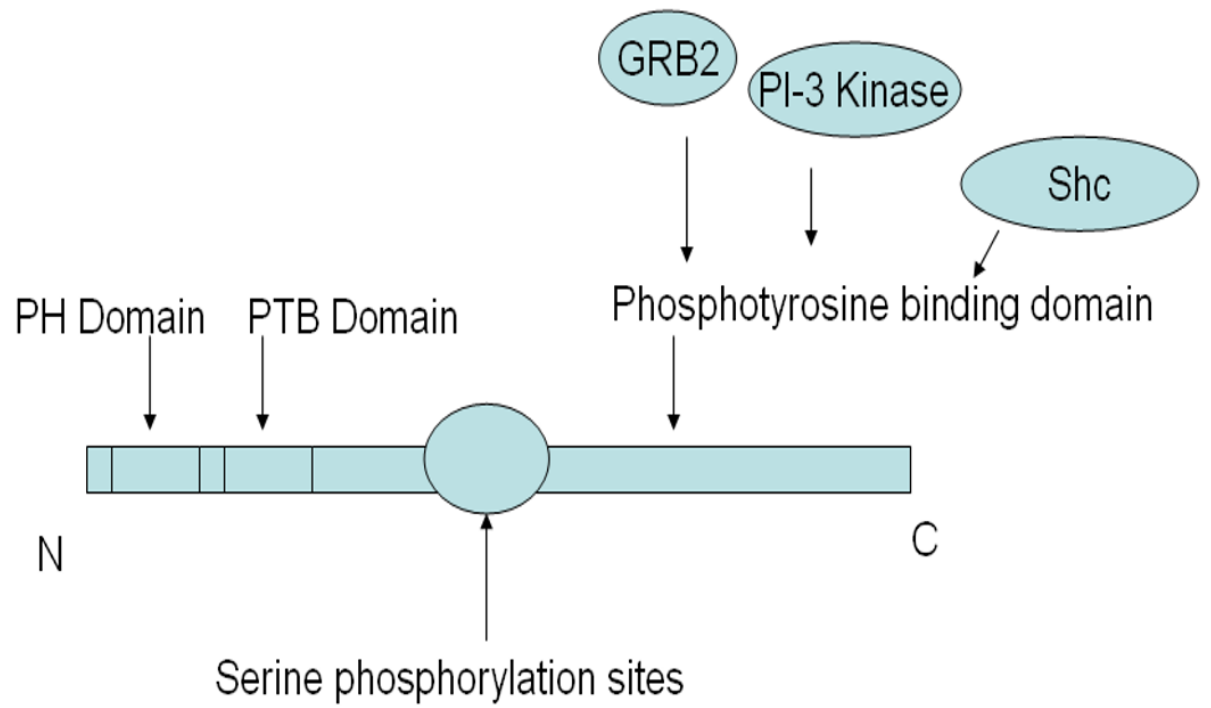

\section{Figure 4}

Structural Determinants of Insulin Receptor Substrates. IRS-I and -2 are considerably similar in their general architecture $[23,24,38]$. They are composed of an NH2-terminal, pleckstrin homology (PH) domain that binds to membrane phospholipids, a phosphotyrosine binding (PTB) domain located just upstream the PH domain and is involved in the recognition of the asparagines-proline-glutamic acid-phosphotyrosine (NPEPY) sequence located in the juxtamembrane region of the insulin receptor $\beta$ subunit, phosphoserine binding domain (PSB), and a less conserved $\mathrm{COOH}$-terminal portion with multiple tyrosine phosphorylation motifs that can bind to specific $\mathrm{SH} 2$ domain-containing proteins.

ences along the insulin signaling and inflammatory pathways.

\section{Objectives}

I) To test whether or not Dahl S rats are more susceptible to high salt-induced insulin-resistance than a matched Dahl $\mathrm{R}$ rats, it is essential to assess and compare genes encoding the insulin receptor substrates -1 and -2 and genes encoding the glucose transporter proteins as follows:

a) Exhaustive candidate gene screening will be done in Dahl S versus R rats.

b) mRNA, protein and enzyme activities of genes involved in the insulin signaling pathway (IRS-1, -2, GLUTs) will be examined on normal, low and high salt diet.

II) To test whether or not Dahl S rats are more susceptible to high salt-induced inflammation than a matched Dahl $\mathrm{R}$ rats, it is essential to first assess and compare genes related to the inflammation pathway (NF-kappa B, TNF$\alpha, J N K)$ and determine if they differ within or between populations as follows:

c) Exhaustive candidate gene screening will be done in Dahl S versus R rats. d) mRNA, protein and enzyme activities of genes involved in the insulin signaling pathway (IRS-1, -2, GLUTs) will be examined on normal, low and high salt diet.

III) To test the combined impact of salt and variations along the insulin and inflammatory pathways, measurement of glucose delivery to the plasma membranes, glucose transport across the plasma membrane and glucose phosphorylation will be performed on normal, low and high salt diet.

IV) To test if these variations identified in objectives I and II are associated with susceptibility to high salt induced insulin resistance, haplotype analyses on candidate genes identified will be of importance.

\section{Methodology}

Question 1: Do variations in genes encoding the insulin receptor substrates -1 and -2 and/or genes encoding the glucose transporter proteins predict salt-induced insulin resistance in Dahl S rats?

Aim 1: Determination of polymorphisms in genes encoding for $\underline{I R S-1,-2 \text { and the GLUTs proteins }}$ 


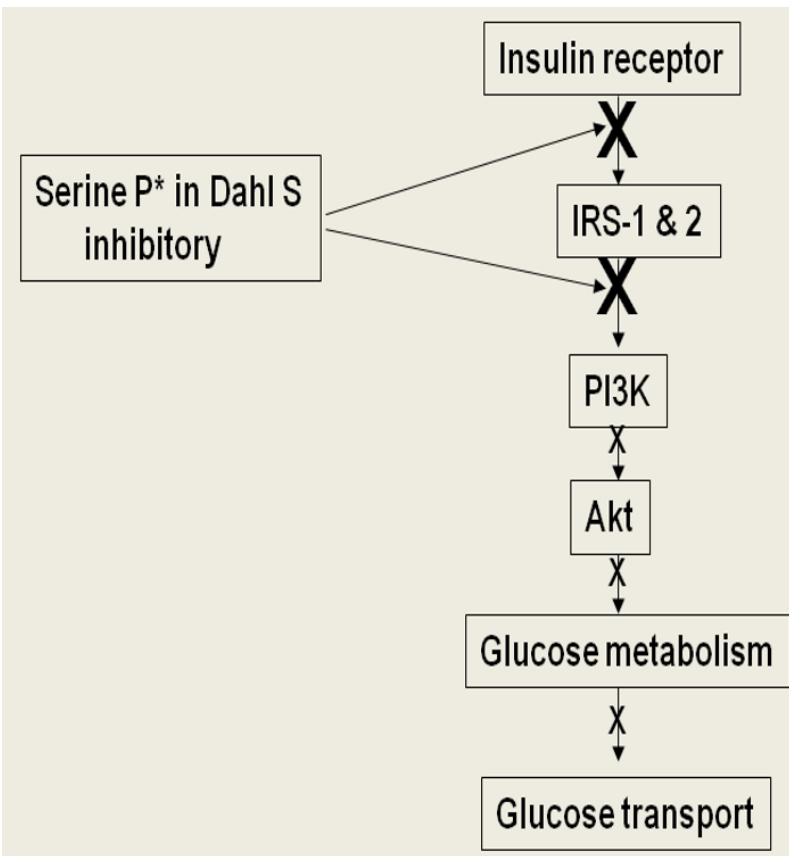

Figure 5

Serine phosphorylation in Dahl S rats precipitates insulin resistance. Dahl $S$ rats are postulated in the current proposal to have increased serine phosphorylation of insulin receptor substrate-I and/or 2 (IRS-I and/or-2) on critical sites such as Ser 312, 616,307, and 323. This in turn reduces their ability to bind and activate either the insulin receptor or the phosphoinositol 3-kinase, resulting in reduced insulinstimulated glucose transport activity and other events downstream of PI3K.

\section{Animals}

To identify putative gender differences to susceptibility to high salt-induced insulin resistance, four-week-old male and female Dahl salt-sensitive (Dahl S) $(\mathrm{n}=200)$ and saltresistant (Dahl $\mathrm{R})(\mathrm{n}=200)$ rats will be purchased from Harlan Sprague Dawley (Indianapolis, IN) and will be fed a standard rodent diet containing $0.3 \% \mathrm{NaCl}$ (normal diet group) or $8 \% \mathrm{NaCl}$ (high-salt group) or $0.03 \% \mathrm{NaCl}$ (low-salt group) during a 4-week experimental period. The rats will be housed in a room maintained at constant humidity $(60 \pm 5 \%)$, temperature $\left(23 \pm 1^{\circ} \mathrm{C}\right)$, and light cycle (12 hours: 0700 to 1900$)$. Food and tap water will be available ad libitum throughout the study. All experimental procedures will be carried out in accordance with the guidelines of the University of Ottawa Animal Care Committee for the care and use of laboratory animals. The rats will be characterized before and after normal, high and low salt diet in terms of: body weights, food intakes, blood pressures and plasma parameters (Fasting blood glucose, fasting plasma insulin). The blood pressure of the rats will be measured every other day by the tail-cuff method using a Softron BP-98A automatic sphygmomanometer [19]. Rats will be acclimated to the procedure daily during the week leading up to study. Blood glucose and plasma will be assayed using the glucose oxidase and radioimmunoassay methods, respectively. This will be performed every week using blood samples obtained from a tail vein (1 ml) [19]. Measurements of blood pressure, blood glucose and plasma insulin will continue till the fourth week post treatment. Prior to sacrificing the rats, Dahl S versus $\mathrm{R}$ rats will be confirmed as insulin resistant using the hyperinsulinemic-euglycemic clamp procedure [19].

\section{Genomic DNA isolation and organ collection}

Rats will be euthanized 4 weeks post treatment and genomic DNA will be isolated from white blood cells using Qiagen Human FlexiGene DNA kit according to the instructions provided by the manufacturer. $5 \mathrm{mls}$ of blood/rat are sufficient to produce ample DNA for our study. Kidney and liver tissues will be collected and immediately flash frozen in liquid nitrogen for mRNA and protein extraction. Kidney and liver tissues are good candidate tissues owing to their importance in the pathogenesis of insulin resistance. Abnormal responses of insulin receptor mRNA levels to high salt intake were reported in kidneys and livers of animal models of insulin resistance such as the spontaneously hypertensive rats (SHR) and the fructose-fed rats $[79,80]$.

Search for polymorphisms in genes encoding for IRS-I, -2 and glucose transporter proteins

Variants currently identified in genes encoding the IRS-1, IRS-2 and GLUTs proteins correlate with insulin resistance. In rats (Sprague Dawley), only one non synonymous polymorphism has been reported in the IRS-1 gene so far. However, functional studies are yet to be determined (Tables 1 and 2). Two independent methods of genotyping namely DHPLC and sequencing will be combined as was done previously [81-84]. DHPLC offers sensitivity of $95 \%-100 \%$ and specificity of $100 \%$ [85], while sequencing offers sensitivity of $99.7 \%-100 \%$ and specificity of $100 \%$ respectively [86]. Combining these highly sensitive and specific methods of genetic screening will help eliminate any false positive or false negative results that might occur with one method of genetic screening. Sequences will be retrieved from the GenBank [GenBank: IRS-1 NM 012969;IRS-2: XM 001076309]. Dahl S and R rats' sequences will be compared to each other and to the Rattus Norvegicus (Brown Norway rat) sequence readily available in the Rat Genome Database. Brown Norway rat sequence will serve as an additional control.

Aim 2: Determination of $m R N A$ and protein expression levels for genes encoding IRS-1, -2 and glucose transporter proteinsm 
Table 3: Chromosomal location, tissue distribution and transcript information of genes encoding glucose transporters

\begin{tabular}{|c|c|c|c|c|c|}
\hline $\begin{array}{l}\text { Gene } \\
\text { Symbol }\end{array}$ & Gene name & $\begin{array}{l}\text { Chromosomal } \\
\text { Location }\end{array}$ & Tissue Distribution & Function & $\begin{array}{l}\text { Transcript } \\
\text { Information }\end{array}$ \\
\hline Slc2al & $\begin{array}{l}\text { facilitated glucose transporter } \\
\text { member I (Glucose transporter } \\
\text { type I) (GLUT-I) }\end{array}$ & $\begin{array}{l}\text { chr5:139690804-13 } \\
9719021\end{array}$ & $\begin{array}{l}\text { All tissues (abundant in } \\
\text { brain and } \\
\text { erythrocytes) }\end{array}$ & Basal uptake & $\begin{array}{l}\text { Exons: I0 } \\
\text { Transcript length: } \\
2,365 \text { bps } \\
\text { Protein length: } 492 \\
\text { residues }\end{array}$ \\
\hline Slc2a2 & $\begin{array}{l}\text { solute carrier family } 2 \text {, facilitated } \\
\text { glucose transporter member } 2 \\
\text { (Glucose transporter type 2) } \\
\text { (GLUT-2) }\end{array}$ & $\begin{array}{l}\text { chr2: II6036427-11 } \\
6065870\end{array}$ & $\begin{array}{l}\text { Liver, pancreatic islet } \\
\text { cells, retina }\end{array}$ & Glucose sensing & $\begin{array}{l}\text { Exons: I } 2 \\
\text { Transcript length: } \\
2,578 \text { bps } \\
\text { Protein length: } 524 \\
\text { residues }\end{array}$ \\
\hline Slc2a3 & $\begin{array}{l}\text { solute carrier family } 2 \text {, facilitated } \\
\text { glucose transporter member } 3 \\
\text { (Glucose transporter type } 3 \text { ) } \\
\text { (GLUT-3) }\end{array}$ & $\begin{array}{l}\text { chr4:159210019-15 } \\
9221248\end{array}$ & $\begin{array}{l}\text { All tissues specially the } \\
\text { brain }\end{array}$ & $\begin{array}{l}\text { Supplements GLUTI in } \\
\text { tissues with high energy } \\
\text { demand }\end{array}$ & $\begin{array}{l}\text { Exons: } 9 \\
\text { Transcript length: } \\
\text { l,467 bps } \\
\text { Protein length: } 488 \\
\text { residues }\end{array}$ \\
\hline Slc2a4 & $\begin{array}{l}\text { solute carrier family } 2 \text {, facilitated } \\
\text { glucose transporter member } 4 \\
\text { (Glucose transporter type } 4 \text { ) } \\
\text { (GLUT-4). }\end{array}$ & $\begin{array}{l}\text { chr 10:56,786,705-5 } \\
6,792,209 .\end{array}$ & Muscle, fat, heart & Insulin responsive & $\begin{array}{l}\text { Exons: II } \\
\text { Transcript length: } \\
2,506 \text { bps } \\
\text { Protein length: } 509 \\
\text { residues }\end{array}$ \\
\hline Slc2a8 & $\begin{array}{l}\text { solute carrier family } 2 \text {, facilitated } \\
\text { glucose transporter member } 8 \\
\text { (Glucose transporter type } 8 \text { ) } \\
\text { (GLUT-8) }\end{array}$ & $\begin{array}{l}\text { chr3:11962578-119 } \\
72099\end{array}$ & $\begin{array}{l}\text { hippocampal neurons, } \\
\text { testis, whole brain }\end{array}$ & & $\begin{array}{l}\text { Exons: I0 } \\
\text { Transcript length: } \\
2,087 \text { bps } \\
\text { Protein length: } 478 \\
\text { residues }\end{array}$ \\
\hline Nagltl & $\begin{array}{l}\text { Sodium dependant glucose } \\
\text { transporter I }\end{array}$ & $\begin{array}{l}\text { chr20:44, I47,33I-4 } \\
4,176,308 .\end{array}$ & In all cells & & $\begin{array}{l}\text { Exons: } 4 \\
\text { Transcript length: } \\
\text { l,455 bps } \\
\text { Protein length: } 484 \\
\text { residues }\end{array}$ \\
\hline Slc37a4 & $\begin{array}{l}\text { solute carrier family } 37 \text { (glucose- } \\
6 \text {-phosphate transporter), } \\
\text { member } 4\end{array}$ & $\begin{array}{l}\operatorname{chr} 8: \\
47,363,896-47,369 \\
981 .\end{array}$ & Liver, Adipocytes & & $\begin{array}{l}\text { Exons: } 9 \\
\text { Transcript length: } \\
2,080 \text { bps } \\
\text { Protein length: } 429 \\
\text { residues }\end{array}$ \\
\hline
\end{tabular}

\section{RNA Quantification}

Kidney, liver and brain tissues will be utilized for total RNA extraction using the Qiagen RNeasy Mini Kit [87-89]. Fold differences in mRNA levels for genes encoding IRS-1, -2 and the GLUTs glucose transporter proteins will be obtained using quantitative RT-PCR [90].

\section{Protein Quantification}

ReadyPrep ${ }^{\mathrm{TM}}$ Protein Extraction Kit (Signal), from Bio-Rad, will be utilized to extract total protein from the kidney, liver and brain tissues of Dahl rats after 4 weeks. The availability of an antiserum specific for the IRS- 1 and -2 and GLUT proteins (Upstate Biotechnology Inc. Lake Placid, NY) will allow us to probe for these proteins in kidney, liver and brain cell homogenates.

\section{Aim 3: Are IRS-1 and-2 differentially phosphorylated on serine} residues
Variations in genes encoding IRS- 1 or -2 might be at the level of DNA (genetic variants) or at the level of serine phosphorylation. In order to examine differential serine phosphorylation of IRS- 1 and -2 in Dahl S, versus R rats, anti-IRS-1 phosphoserine antibody will be utilized to probe kidney, liver and brain samples from low, regular and high salt diet. Fold increase or decrease in IRS-1 and 2 serine phosphorylation in Dahl S rats post dietary treatment will be compared with control Dahl R rats.

Ogihara et al., in 2002 reported an enhanced tyrosine phosphorylation of the insulin receptor, insulin receptor substrates, PI3K activation and serine phosphorylation of Akt in Dahl S versus R rats [19]. However, there were some limitations to the procedures they used. First, Dahl rats were fasted for 12 hours prior to the experiment assessing IRS-1 and -2 phosphorylation. Fasting is reported to enhance insulin-induced IRS-1 and IRS-2 tyrosine phosphorylation and association with PI3-kinase in liver and muscle of animal models of insulin resistance (streptozo- 
Table 4: Previously reported variant (s) in genes encoding glucose transporter proteins

\begin{tabular}{|c|c|c|c|c|c|}
\hline Gene & Strain & Type & Residue & SNP & Amino Acid \\
\hline Slc2al & $\begin{array}{l}\text { Sprague Dawley } \\
\text { Ref: Brown Norway }\end{array}$ & Synonymous & 383 & ENSRNOSNPI 925604 & $\mathrm{C} / \mathrm{T}$ \\
\hline \multirow[t]{3}{*}{ Slc2a2 } & $\begin{array}{l}\text { Sprague Dawley } \\
\text { Ref: Brown Norway }\end{array}$ & Non-synonymous & 475 & ENSRNOSNPI I 65255 & $A / G$ \\
\hline & $\begin{array}{l}\text { Sprague Dawley } \\
\text { Ref: Brown Norway }\end{array}$ & Non-synonymous & 512 & ENSRNOSNPII 65256 & $\mathrm{G} / \mathrm{A}$ \\
\hline & $\begin{array}{l}\text { Sprague Dawley } \\
\text { Ref: Brown Norway }\end{array}$ & Synonymous & 520 & ENSRNOSNPI I 65257 & T/A \\
\hline \multirow[t]{4}{*}{ SIc2a3 } & $\begin{array}{l}\text { Sprague Dawley } \\
\text { Ref: Brown Norway }\end{array}$ & Non-synonymous & 50 & rs8I72435 & $\mathrm{G} / \mathrm{C}$ \\
\hline & $\begin{array}{l}\text { Sprague Dawley } \\
\text { Ref: Brown Norway }\end{array}$ & Synonymous & 147 & rs8160316 & $\mathrm{A} / \mathrm{C}$ \\
\hline & $\begin{array}{l}\text { Sprague Dawley } \\
\text { Ref: Brown Norway }\end{array}$ & Non-synonymous & 442 & rs8I72437 & $A / G$ \\
\hline & $\begin{array}{l}\text { Sprague Dawley } \\
\text { Ref: Brown Norway }\end{array}$ & Non-synonymous & 465 & rs8172438 & $C / G$ \\
\hline Naglt I & $\begin{array}{l}\text { Sprague Dawley } \\
\text { Ref: Brown Norway }\end{array}$ & Non-synonymous & 166 & ENSRNOSNPI5I 3056 & C/A \\
\hline
\end{tabular}

Previously reported variants in the glucose transporters in the Sprague Dawley rat. The reference strain was the Brown Norway rat [133].

tocin treated rats) [91]. Secondly, the authors injected insulin in the portal vein of rats once after which immediately they harvested livers and hindlimb muscles for measuring the IRS-1 and -2 levels and tyrosyl phosphorylation. Co-immunoprecipitation experiments of IRS-1 and -2 were done in triplicates. Regardless of the fact that the authors has done the insulin injection once and then repeated the immunoblotting experiment three times on the harvested liver and hindlimbs of Dahl rats, it is documented that within 1 minute of acute insulin stimulation, enhancement of the insulin signaling pathway and augmentation of IRS content and tyrosyl phosphorylation together with PI3K activation occur $[92,93]$. On the contrary, chronic effects of insulin have been shown to enhance IRS-1 serine phosphorylation preventing its subsequent tyrosine phosphorylation [94]. Therefore fasting and acute insulin injection in Dahl S rats (a model of insulin resistance) were additive in enhancing the insulin signaling pathway. It would have been more proper to show the impact of chronic insulin stimulation in high-salt-fed Dahl S rats without fasting or acute insulin stimulation, both of which might have misrepresented the actual defects in insulin signaling in Dahl S rats. Therefore, I propose to use the same procedure adopted by Sechi et .al., 1997, where the animals were neither fasted nor injected insulin prior to the experiment [95].

It is also possible that even in the presence of enhanced IRS-1 and/or -2 tyrosyl phosphorylation in Dahl S rats that enhanced serine phosphorylation in Dahl $S$ rats would be the mechanism behind high salt-induced insulin resistance in this model. Serine phosphorylation might induce some conformational change that does not affect tyrosine phosphorylation but inhibits the insulin signaling pathway, via rapid tyrosyl dephosphorylation and deactivation or by acting as inhibitors to the insulin receptor kinase [40-42].

High salt might as well exert an additional inhibitory effect on IRS-1 and -2, possibly by interacting with a sodium-binding sequence $[13,14]$ on the IRS-1 and/or -2 genes to suppress their mRNA and/or protein levels in Dahl S versus $\mathrm{R}$ rats. I was able to locate a sodium response element in the proximal promoters of IRS-1 and IRS-2 genes. As such, associations between high salt intake and insulin resistance might exist through the IRS-1 and/or -2 genes.

Aim 4: Determination of the impact of any variant/variants on the activity of IRS-1 and IRS-2, GLUTS

To test the impact of identified 5 ' flanking region variant(s) on the activity of IRS-1, IRS- 2 and GLUTs, reporter genes can be used to assay for the activity of the promotor in a cell. The reporter gene (e.g. luciferase or GFP) is placed under the control of the IRS-1 or IRS- 2 or GLUT promotor and the reporter gene product's activity is quantitatively measured. The results are normally reported relative to the activity under a "consensus" promoter known to induce strong gene expression. For variants identified in the coding region, we will assess the impact of such variant in altering the resultant amino acid sequence. The IRS-1 and IRS-2 constructs will be prepared using the same techniques we previously optimized $[87,88,90]$. Briefly, RT-PCR will be employed to amplify full length genes with the variant (s) identified from Dahl S rats' 
Table 5: List of Major Candidate Genes Involved in the Inflammation Pathway

\begin{tabular}{|c|c|c|c|c|}
\hline Gene Symbol & Gene Name & $\begin{array}{l}\text { Chromosomal } \\
\text { Location }\end{array}$ & Transcript information & Justification \\
\hline TNF- $\alpha$ & $\begin{array}{l}\text { tumor necrosis factor } \\
\text { receptor superfamily }\end{array}$ & $\begin{array}{l}\text { chr3:I56092602-156107 } \\
426\end{array}$ & $\begin{array}{l}\text { Exons: } 9 \\
\text { Transcript length: } \\
\text { I,247 bps } \\
\text { Protein length: } 289 \\
\text { residues }\end{array}$ & $\begin{array}{l}\text { TNF- } \alpha \text {, a potential mediator of } \\
\text { insulin resistance, promotes } \\
\text { serine phosphorylation of IRS- } \\
\text { I and }-2 \text {, impairs the ability of } \\
\text { IRS-I and }-2 \text { to associate with } \\
\text { the insulin receptor and } \\
\text { inhibits insulin-stimulated } \\
\text { tyrosine phosphorylation } \\
\text { [54-56]. TNF- } \alpha \text { is upregulated } \\
\text { in Dahl S rats [52]. }\end{array}$ \\
\hline $\begin{array}{l}\text { NF-kappa-B- } \\
\text { activating protein }\end{array}$ & $\begin{array}{l}\text { Nuclear factor kappa-B- } \\
\text { activating protein }\end{array}$ & $\begin{array}{l}\text { chr X: } \\
7,762,299-7,781,765 .\end{array}$ & $\begin{array}{l}\text { Exons: } 9 \\
\text { Transcript length: } \\
\text { I,248 bps } \\
\text { Protein length: } 415 \\
\text { residues }\end{array}$ & $\begin{array}{l}\text { Renal NF-\{kappa\}B is } \\
\text { significantly upregulated in } \\
\text { high-salt-fed Dahl S rats [58]. }\end{array}$ \\
\hline NF-IKBKB & $\begin{array}{l}\text { Nuclear factor kappa-B } \\
\text { kinase subunit beta }\end{array}$ & $\begin{array}{l}\text { chrl6: } \\
73,805,082-73,858,088 .\end{array}$ & $\begin{array}{l}\text { Exons: } 2 \text { I } \\
\text { Transcript length: } \\
\text { 3,022 bps } \\
\text { Protein length: } 757 \\
\text { residues }\end{array}$ & $\begin{array}{l}\text { Inhibition of IKBKB with } \\
\text { salicylates or through targeted } \\
\text { gene disruption causes a } \\
\text { dramatic improvement of } \\
\text { insulin sensitivity in animal } \\
\text { models of insulin resistance } \\
\text { such as ob/ob mice and obese } \\
\text { Zucker fatty rats }[59,60] .\end{array}$ \\
\hline ILI $\beta$ & $\begin{array}{l}\text { Interleukin- } \mid \beta \text { receptor } \\
\text { accessory protein } \\
\text { precursor }\end{array}$ & $\begin{array}{l}\text { chrll: } \\
76,092,840-76,222,495 .\end{array}$ & $\begin{array}{l}\text { Exons: II } \\
\text { Transcript length: } \\
\text { I,862 bps } \\
\text { Protein length: } 570 \\
\text { residues }\end{array}$ & $\begin{array}{l}\text { ILI } \beta \text { activates jnk which is } \\
\text { upregulated in high-salt-fed } \\
\text { Dahl } S \text { rats [57]. }\end{array}$ \\
\hline ILI Id & interleukin I7D & $\begin{array}{l}\operatorname{chr} \text { 15: } \\
36,566,307-36,583,168 .\end{array}$ & $\begin{array}{l}\text { Exons: } 9 \\
\text { Transcript length: } 62 \text { I } \\
\text { bps } \\
\text { Protein length: } 206 \\
\text { residues }\end{array}$ & $\begin{array}{l}\text { IL-I7 D, a proinflammatory } \\
\text { cytokine that enhances T cell } \\
\text { priming and stimulates the } \\
\text { production of proinflammatory } \\
\text { molecules such as IL-I, IL-6, } \\
\text { TNF-alpha, NOS-2, and } \\
\text { chemokines resulting in } \\
\text { inflammation. }\end{array}$ \\
\hline ILIO & $\begin{array}{l}\text { Interleukin-10 precursor } \\
\text { (IL-I0) (Cytokine } \\
\text { synthesis inhibitory } \\
\text { factor) (CSIF). }\end{array}$ & chr 13: $43.95 \mathrm{~m}$ & $\begin{array}{l}\text { Exons: } 5 \\
\text { Transcript length: } \\
\text { I,289 bps } \\
\text { Protein length: I } 78 \\
\text { residues }\end{array}$ & $\begin{array}{l}\text { IL-I0, also known as human } \\
\text { cytokine synthesis inhibitory } \\
\text { factor (CSIF), is an anti- } \\
\text { inflammatory cytokine. This } \\
\text { cytokine can block NF-kappa B } \\
\text { activity, and is involved in the } \\
\text { regulation of the JAK-STAT } \\
\text { signaling pathway. It is capable } \\
\text { of inhibiting synthesis of pro- } \\
\text { inflammatory cytokines like } \\
\text { Interferon-gamma, IL-2, IL-3, } \\
\text { TNF } \alpha \text { and GM-CSF made by } \\
\text { cells such as macrophages and } \\
\text { the Type I T helper cells. }\end{array}$ \\
\hline Crp & $\begin{array}{l}\text { C-reactive protein } \\
\text { precursor }\end{array}$ & $\begin{array}{l}\text { chr 13: } \\
88,674,743-88,7 \mid 5,585 .\end{array}$ & $\begin{array}{l}\text { Exons: } 2 \\
\text { Transcript length: } \\
\text { I,655 bps } \\
\text { Protein length: } 230 \\
\text { residues }\end{array}$ & $\begin{array}{l}\text { Insulin resistance and C- } \\
\text { reactive protein (CRP) levels } \\
\text { are strongly correlated in } \\
\text { adults }\left[\begin{array}{lll}1 & 10\end{array}\right]\end{array}$ \\
\hline Ratsg2 & $\begin{array}{l}\text { Selenoprotein S (VCP- } \\
\text { interacting membrane } \\
\text { protein) (Sg2). }\end{array}$ & $\begin{array}{l}\text { chr I: } \\
\text { I20,509, I28-120,5 I8,32 } \\
2 .\end{array}$ & $\begin{array}{l}\text { Exons: } 6 \\
\text { Transcript length: } 573 \\
\text { bps } \\
\text { Protein length: } 190 \\
\text { residues }\end{array}$ & $\begin{array}{l}\text { In humans, polymorphisms in } \\
\text { the encoded plama membrane } \\
\text { selenoprotein (SEPSI, or SELS } \\
\text { gene) correlate to diabetes } \\
\text { mellitus and coronary heart } \\
\text { diseases. The selenoprotein } \\
\text { regulate red-ox balance and } \\
\text { clear cells of misfolded } \\
\text { proteins. Gene polymorphisms } \\
\text { result in accumulation of these } \\
\text { proteins even higher under cell } \\
\text { stress. Carriers have higher } \\
\text { ILI, -6, - I0, and TNF [III]. }\end{array}$ \\
\hline
\end{tabular}


Table 5: List of Major Candidate Genes Involved in the Inflammation Pathway (Continued)

\begin{tabular}{|c|c|c|c|c|}
\hline Ptpn22_predicted & $\begin{array}{l}\text { Protein tyrosine } \\
\text { phosphatase, non- } \\
\text { receptor type } 22 \\
\text { (lymphoid) (predicted) }\end{array}$ & $\begin{array}{l}\text { chr 2: } \\
\text { 199,083,234-199, I32,76 } \\
\text { I }\end{array}$ & $\begin{array}{l}\text { Exons: } 22 \\
\text { Transcript length: } \\
\text { 2,476 bps } \\
\text { Protein length: } 803 \\
\text { residues }\end{array}$ & $\begin{array}{l}\text { Tyrosine phosphatase gene } \\
\text { (PTPN22) prevents } \\
\text { spontaneous T-cell activation. } \\
\text { In humans, mutations } \\
\text { (CI858T, R620W) was } \\
\text { associated with type I diabetes } \\
\text { [II2-II4]. }\end{array}$ \\
\hline Crhrl & $\begin{array}{l}\text { Corticotropin-releasing } \\
\text { factor receptor I } \\
\text { precursor (CRF-R) } \\
\text { (CRFI) (Corticotropin- } \\
\text { releasing hormone } \\
\text { receptor I) (CRH-R I). }\end{array}$ & chr 10: 93.31 m & $\begin{array}{l}\text { Exons: I } 2 \\
\text { Transcript length: } \\
\text { I,2 I } 8 \text { bps } \\
\text { Protein length: } 405 \\
\text { residues }\end{array}$ & $\begin{array}{l}\text { Crhrl is required for a normal } \\
\text { chromaffin cell structure and } \\
\text { function and deletion of this } \\
\text { gene is associated with a } \\
\text { significant impairment of } \\
\text { epinephrine release. }\end{array}$ \\
\hline IL6 & Interleukin-6 precursor & chr 4: 456,799-46I,376. & $\begin{array}{l}\text { Exons: } 6 \\
\text { Transcript length: } \\
\text { l,042 bps } \\
\text { Protein } n \text { length: } 210 \\
\text { residues }\end{array}$ & $\begin{array}{l}\text { Impaired glucose tolerance is } \\
\text { associated with increased } \\
\text { serum concentrations of } \\
\text { interleukin } 6 \text { [1 I5]. }\end{array}$ \\
\hline ILI 5 & Interleukin-I5 precursor. & $\begin{array}{l}\text { chr 19: } \\
27,482,376-27,499,255 \text {. }\end{array}$ & $\begin{array}{l}\text { Exons: } 6 \\
\text { Transcript length: } 768 \\
\text { bps } \\
\text { Protein length: } 16 \mathrm{I} \\
\text { residues }\end{array}$ & $\begin{array}{l}\text { IL-I5 increases insulin } \\
\text { sensitivity therefore increasing } \\
\text { glucose transport and } \\
\text { utilization in muscles [116]. }\end{array}$ \\
\hline ILI 8 & interleukin 18 & $\begin{array}{l}\text { chr 9: } \\
39,676,026-39,698,748 .\end{array}$ & $\begin{array}{l}\text { Exons: I0 } \\
\text { Transcript length: } \\
\text { I,884 bps } \\
\text { Protein length: } 604 \\
\text { residues }\end{array}$ & $\begin{array}{l}\text { Elevated plasma interleukin- } 18 \\
\text { is a marker of insulin- } \\
\text { resistance in type } 2 \text { diabetic } \\
\text { and non-diabetic humans } \\
{[117,118] .}\end{array}$ \\
\hline Map2k7 & $\begin{array}{l}\text { Dual specificity mitogen- } \\
\text { activated protein kinase } \\
\text { kinase } 7\end{array}$ & $\begin{array}{l}\text { chr I2: } \\
\text { I,543,467-I,552,353. }\end{array}$ & $\begin{array}{l}\text { Exons: I } 3 \\
\text { Transcript length: } \\
\text { l,407 bps } \\
\text { Protein length: } 468 \\
\text { residues }\end{array}$ & $\begin{array}{l}\text { MAP2K7 selectively activates } \\
\text { the JNKs which suppresses } \\
\text { insulin signaling [57]. }\end{array}$ \\
\hline Mapk6 & $\begin{array}{l}\text { Mitogen-activated protein } \\
\text { kinase } 6 \text { or (Extracellular } \\
\text { signal-regulated kinase } 3) \\
\text { (ERK-3) (p55-MAPK). }\end{array}$ & $\begin{array}{l}\operatorname{chr} 8: \\
80,212,726-80,236,362\end{array}$ & $\begin{array}{l}\text { Exons: } 6 \\
\text { Transcript length: } \\
4,180 \text { bps } \\
\text { Protein length: } 720 \\
\text { residues }\end{array}$ & $\begin{array}{l}\text { ERK3 associates with MAP2 } \\
\text { and is involved in glucose- } \\
\text { induced insulin secretion } \\
\text { [119]. }\end{array}$ \\
\hline Map4k4 & $\begin{array}{l}\text { Mitogen-activated protein } \\
\text { kinase 4-isoform4 }\end{array}$ & $\begin{array}{l}\text { chr 9: } \\
39,070,845-39,211,446 .\end{array}$ & $\begin{array}{l}\text { Exons: } 34 \\
\text { Transcript length: } \\
\text { 4,40 I bps Translation } \\
\text { length: } 1,232 \text { residues }\end{array}$ & $\begin{array}{l}\text { Map4k4 gene silencing in } \\
\text { human skeletal muscle } \\
\text { prevents tumor necrosis } \\
\text { factor-alpha-induced insulin } \\
\text { resistance [120]. }\end{array}$ \\
\hline Map2k I & $\begin{array}{l}\text { Dual specificity mitogen- } \\
\text { activated protein kinase } \\
\text { kinase I or (MAP kinase } \\
\text { kinase I) (MAPKK I) } \\
\text { (ERK activator kinase I) } \\
\text { (MAPK/ERK kinase I) } \\
\text { (MEK I). }\end{array}$ & $\begin{array}{l}\text { chr 8: } \\
68,379,077-68,451,583 \text {. }\end{array}$ & $\begin{array}{l}\text { Exons: II } \\
\text { Transcript length: } \\
\text { 2, I } 20 \text { bps } \\
\text { Protein length: } 393 \\
\text { residues }\end{array}$ & $\begin{array}{l}\text { MAP2KI restored insulin } \\
\text { action on glucose uptake by } \\
\text { cells }[120,121] \text {. }\end{array}$ \\
\hline Jnk & $\begin{array}{l}\text { C-Jun amino terminal } \\
\text { kinase }\end{array}$ & chr 3: $76.78 \mathrm{~m}$ & $\begin{array}{l}\text { Exons: I } 2 \\
\text { Transcript length: } \\
\text { 2,992 bps } \\
\text { Protein length: } 699 \\
\text { residues }\end{array}$ & $\begin{array}{l}\text { JnK is activated by TNF- } \alpha \text { and } \\
\text { IL- } \beta \text {. Jnk forms a stable } \\
\text { complex with IRS-I and } \\
\text { phosphorylates Ser } 307 \text { that } \\
\text { inhibits insulin stimulated } \\
\text { tyrosine phosphorylation of } \\
\text { IRS-I [57]. }\end{array}$ \\
\hline Cx3crl & $\begin{array}{l}\text { CX3C chemokine } \\
\text { receptor I }\end{array}$ & chr 8: $125.03 \mathrm{~m}$ & $\begin{array}{l}\text { Exons: } 2 \\
\text { Transcript length: } \\
\text { I,326 bps } \\
\text { Protein length: } 354 \\
\text { residues }\end{array}$ & $\begin{array}{l}\text { Modulators of CX3CRI can be } \\
\text { used to treat diabetes, as well } \\
\text { as diagnose diabetes by } \\
\text { measuring the levels of } \\
\text { CX3CR I in a patient (US } \\
\text { patents 2006). }\end{array}$ \\
\hline Ccr3 & $\begin{array}{l}\text { C-C chemokine receptor } \\
\text { type } 3\end{array}$ & chr 8: I28.76 m & $\begin{array}{l}\text { Exons: } 2 \\
\text { Transcript length: } \\
\text { I,3 I } 5 \text { bps } \\
\text { Protein length: } 359 \\
\text { residues }\end{array}$ & $\begin{array}{l}\mathrm{CCL} 3 \text { was reported to be } \\
\text { increased in obese mice and to } \\
\text { contribute to insulin resistance } \\
\text { and macrophage recruitment } \\
{[122] \text {. }}\end{array}$ \\
\hline
\end{tabular}


Table 5: List of Major Candidate Genes Involved in the Inflammation Pathway (Continued)

\begin{tabular}{|c|c|c|c|c|}
\hline Ccr2 & $\begin{array}{l}\text { C-C chemokine receptor } \\
\text { type } 2\end{array}$ & chr 8: $128.89 \mathrm{~m}$ & $\begin{array}{l}\text { Exons: I } \\
\text { Transcript length: } \\
\text { I, I } 22 \text { bps } \\
\text { Protein length: } 373 \\
\text { residues }\end{array}$ & $\begin{array}{l}\text { CCR2 influences the } \\
\text { development of obesity and } \\
\text { associated adipose tissue } \\
\text { inflammation and systemic } \\
\text { insulin resistance [123]. }\end{array}$ \\
\hline Ccr5 & $\begin{array}{l}\text { C-C chemokine receptor } \\
\text { type } 5\end{array}$ & chr 8: I28.9I m & $\begin{array}{l}\text { Exons: } 2 \\
\text { Transcript length: } \\
\text { 2,495 bps } \\
\text { Protein length: } 354 \\
\text { residues }\end{array}$ & $\begin{array}{l}\text { CCR5 polymorphisms in } \\
\text { children with insulin- } \\
\text { dependent diabetes mellitus } \\
\text { [124]. }\end{array}$ \\
\hline Nox3 & NADPH oxidase 3 & chr I: 38.64 m & $\begin{array}{l}\text { Exons: I } 4 \\
\text { Transcript length: } \\
\text { I,76 I bps } \\
\text { Protein length: } 586 \\
\text { residues }\end{array}$ & $\begin{array}{l}\text { NOX3, a ROS generating } \\
\text { NADPH oxidase, plays an } \\
\text { integral role in insulin-induced } \\
\text { signal transmission [ } 125] \text {. }\end{array}$ \\
\hline Nox4 & NADPH oxidase 4 & chr I: $143.42 \mathrm{~m}$ & $\begin{array}{l}\text { Exons: I } 8 \\
\text { Transcript length: } \\
\text { 2,I76 bps } \\
\text { Protein length: } 578 \\
\text { residues }\end{array}$ & $\begin{array}{l}\text { The NAD }(\mathrm{P}) \mathrm{H} \text { Oxidase } \\
\text { Homolog Nox4 Modulates } \\
\text { Insulin-Stimulated Generation } \\
\text { of } \mathrm{H} 2 \mathrm{O} 2 \text { and Plays an Integral } \\
\text { Role in Insulin Signal } \\
\text { Transduction [126]. }\end{array}$ \\
\hline Ptgs2 & $\begin{array}{l}\text { Prostaglandin G/H } \\
\text { synthase } 2 \text { precursor } \\
\text { (Cyclooxygenase-2) } \\
\text { (COX-2) (Prostaglandin } \\
\text { H2 synthase 2) (PGH } \\
\text { synthase 2) (PGHS-2) } \\
\text { (PHS II). }\end{array}$ & $\begin{array}{l}\text { chr I3: } \\
64,427,282-64,432,982 .\end{array}$ & $\begin{array}{l}\text { Exons: I0 } \\
\text { Transcript length: } \\
\text { I,825 bps } \\
\text { Protein length: } 604 \\
\text { residues }\end{array}$ & $\begin{array}{l}\text { PTGS2 generates } \\
\text { prostaglandins, which } \\
\text { negatively modulate glucose- } \\
\text { stimulated insulin secretion, } \\
\text { and functions as a mediator of } \\
\text { the inflammatory response } \\
\text { [127]. }\end{array}$ \\
\hline Alox 5 & $\begin{array}{l}\text { Arachidonate 5- } \\
\text { lipoxygenase (5- } \\
\text { lipoxygenase) (5-LO) }\end{array}$ & chr 4: $152.61 \mathrm{~m}$ & $\begin{array}{l}\text { Exons: I } 4 \\
\text { Transcript length: } \\
2,450 \text { bps } \\
\text { Protein length: } 674 \\
\text { residues }\end{array}$ & $\begin{array}{l}\text { The epidemiologic data suggest } \\
\text { that subjects with two variant } \\
\text { alleles will have greater } \\
\text { ALOX5 gene expression, } \\
\text { greater production of } \\
\text { arachidonic acid-derived } \\
\text { leukotrienes and a more } \\
\text { "proinflammatory phenotype } \\
\text { than subjects with two } \\
\text { common alleles. }\end{array}$ \\
\hline Alox5ap & $\begin{array}{l}\text { Arachidonate 5- } \\
\text { lipoxygenase-activating } \\
\text { protein (FLAP) (MK-886- } \\
\text { binding protein). }\end{array}$ & chr I2: $6.25 \mathrm{~m}$ & $\begin{array}{l}\text { Exons: } 5 \\
\text { Transcript length: } 937 \\
\text { bps } \\
\text { Protein length: } 161 \\
\text { residues }\end{array}$ & $\begin{array}{l}\text { ALOX5AP expression, but not } \\
\text { gene haplotypes, is associated } \\
\text { with obesity and insulin } \\
\text { resistance [128]. }\end{array}$ \\
\hline Nos3 & $\begin{array}{l}\text { Nitric-oxide synthase, } \\
\text { endothelial (NOSIII) } \\
\text { (Endothelial NOS) } \\
\text { (eNOS) }\end{array}$ & $\operatorname{chr} 4: 6.16 \mathrm{~m}$ & $\begin{array}{l}\text { Exons: } 26 \\
\text { Transcript length: } \\
\text { 3,953 bps } \\
\text { Protein length: } 1,202 \\
\text { residues }\end{array}$ & $\begin{array}{l}\text { The (-)786T-C mutation of the } \\
\text { eNOS gene is associated with } \\
\text { insulin resistance in both } \\
\text { Japanese non-diabetic subjects } \\
\text { and Type II diabetic patients } \\
\text { [129] }\end{array}$ \\
\hline Nos2 & $\begin{array}{l}\text { Nitric oxide synthase, } \\
\text { inducible (NOS type II) } \\
\text { (Inducible NO synthase) } \\
\text { (Inducible NOS) (iNOS) }\end{array}$ & chr 10: $65.04 \mathrm{~m}$ & $\begin{array}{l}\text { Exons: } 27 \\
\text { Transcript length: } \\
4,106 \text { bps } \\
\text { Protein length: I, I } 47 \\
\text { residues }\end{array}$ & $\begin{array}{l}\text { obese Nos2 }-1-\text { mice exhibited } \\
\text { improved glucose tolerance, } \\
\text { normal insulin sensitivity in vivo } \\
\text { and normal insulin-stimulated } \\
\text { glucose uptake in muscles } \\
\text { [130]. }\end{array}$ \\
\hline Cpr & $\begin{array}{l}\text { NADPH-cytochrome } \\
\text { P450 reductase (CPR) } \\
\text { (P450R). }\end{array}$ & chr 12: $22.08 \mathrm{~m}$ & $\begin{array}{l}\text { Exons: I } 6 \\
\text { Transcript length: } \\
\text { 2,438 bps } \\
\text { Protein length: } 678 \\
\text { residues }\end{array}$ & $\begin{array}{l}\text { NADPH-cytochrome } \mathrm{P} 450 \\
\text { reductase (CPR) plays a role in } \\
\text { type II diabetes [13I] }\end{array}$ \\
\hline Pla2glb & $\begin{array}{l}\text { Phospholipase A2 } \\
\text { precursor }\end{array}$ & chr 12: $42.41 \mathrm{~m}$ & $\begin{array}{l}\text { Exons: } 4 \\
\text { Transcript length: } 543 \\
\text { bps } \\
\text { Protein length: I } 46 \\
\text { residues }\end{array}$ & $\begin{array}{l}\text { Mice with targeted inactivation } \\
\text { of the group IB phospholipase } \\
\text { A [2] (Pla2glb) gene displayed } \\
\text { lower postprandial glycemia } \\
\text { than that observed in wild-type } \\
\text { mice after being fed a glucose- } \\
\text { rich meal [132]. }\end{array}$ \\
\hline
\end{tabular}




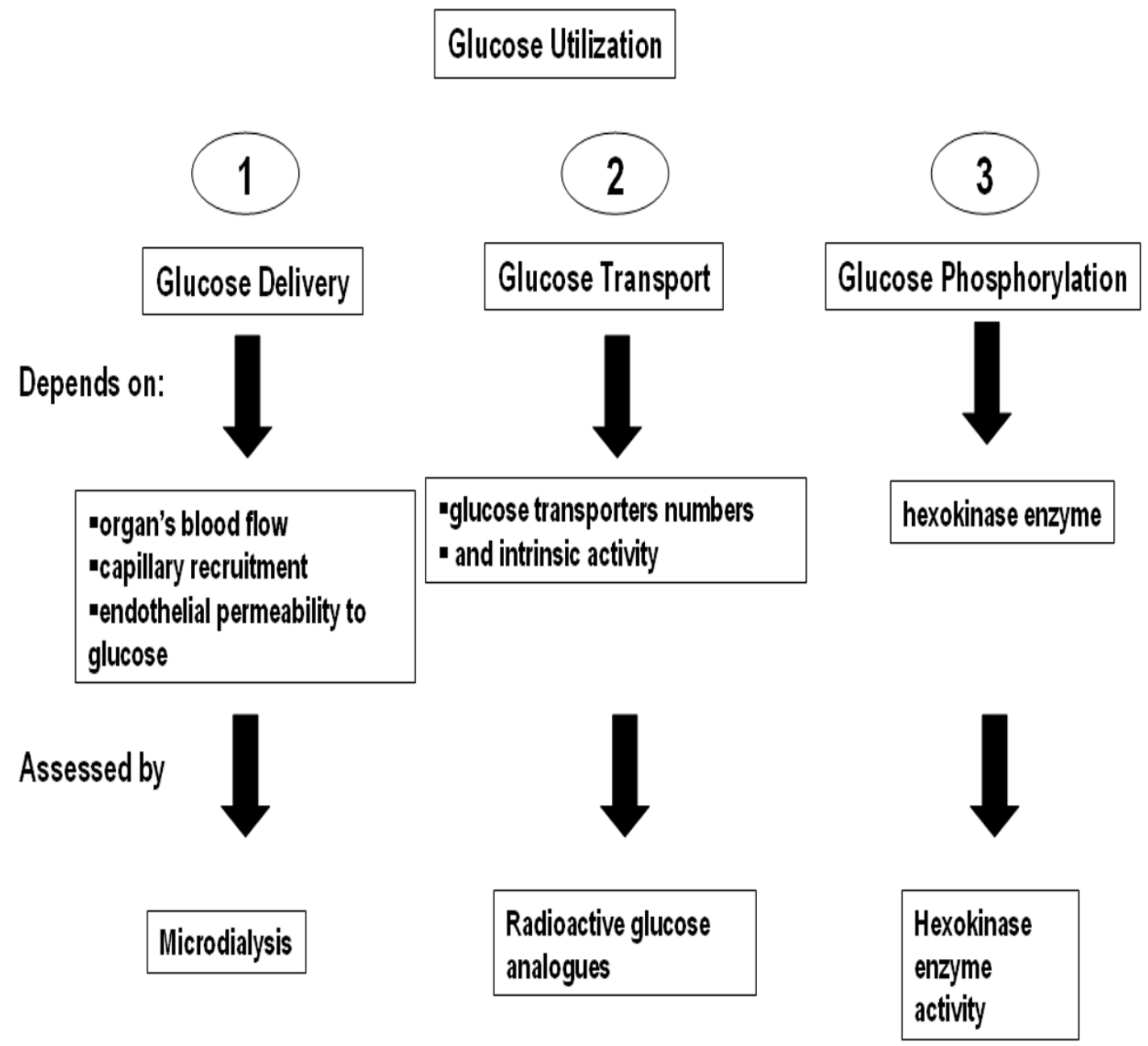

\section{Figure 6}

Steps Involved in Glucose Utilization. Schematic representation of the three steps involved in glucose utilization. In most cases, glucose transport is believed to be the rate limiting step. However, in conditions of hyperinsulinemia like that seen in high-salt-fed Dahl S rats, the rate limiting step may switch to phosphorylation $[63,64]$. Pertubations in any of these steps might precipitate the high salt-induced insulin resistance in Dahl $\mathrm{S}$ rats.

cDNA. Full length constructs from Dahl R rats' cDNA will be used as a control. Representative kidney and liver cell lines such as COS-7 cells and HepG2 cells respectively will be transfected with either the mutant or the corresponding wildtype as control. mRNA and protein levels will be further assessed by QRT-PCR and western blotting respectively to test the impact of such variant (s) in altering the mRNA and/or protein levels. Co-transfection studies will be performed to investigate the impact of combined variants in altering the mRNA and protein expression of IRS1 and IRS-2, and whether a synergistic or an inhibitory response will be the outcome of such combination.
Question 2: What genes, independently or in synergy, along the inflammatory pathway are predictive of high salt-induced insulin resistance in Dahl S rats?

Aim 1: Determination of expression levels of candidate genes along the inflammatory pathway

The somewhat disappointing results of linkage studies for multi-factorial phenotypes coupled with the theory that an individual phenotype results from the cumulative effects of several contributing loci, has lead genetic investigators back to the study of candidate genes in case-control designs [96]. Identification of such candidates has become increasingly rapid with modern molecular methods such as microarrays. High-throughput microarray 
platforms are capable of measuring the expression of thousands of genes simultaneously allowing for the identification of genes that are differentially expressed in tissues from various individuals. Despite the recognized limitations (variation in expression resulting from polymorphism, environmental variation, or RNA quality) they can potentially reveal novel molecular mechanisms contributing to phenotypes as well as uncover alternate candidate genes derived without previous bias. As such, cDNA microarrays offers:i) detection of previously unsuspected genes with a likely role in inflammation, ii) followup of much over and underexpresion of gene populations compared with controls, iii) identification of phenotypically-associated specific patterns of gene expression.

Before pursuing genes along the inflammatory pathway (TNF- $\alpha$, JNK and NF-kappa B ) (Table 5), fold differences in mRNA levels will be obtained in microarray experiments and confirmed using quantitative RT-PCR. Hence haplotype analyses will only be performed on those genes whose mRNA expression patterns, protein levels or activity, significantly differ within or between the Dahl S and R population pre and post-high salt diet. Despite the high cost associated with the use of microarrays, they will enable us to identify potential inflammatory genes whose expression might be altered by diet in Dahl S versus $\mathrm{R}$ rats, and might likely influence insulin resistance in Dahl rats. Microarrays will also eliminate the most time consuming and expensive component of a future candidate gene study, and will simply direct our genetic focus to potential and differentially expressed candidate genes.

Aim 2: Searching for polymorphisms in candidate genes along the inflammatory pathway (Methodology Section-Question 1 Aim 1).

Aim 3: Determination of the impact of any variant/variants on the activity of TNF- $\alpha$, INK and NF-kappa B (Methodology Section-Question 1 Aim 4)

\section{Aim 4: Construction of SNPs haplotypes}

For haplotype construction, previously reported polymorphisms (mostly SNPs) will be identified for each candidate gene by a careful screening of available polymorphism databases. This approach is enhanced by the completion of the rat genome sequence by the Rat Genome Sequencing Project Consortium and the rapidly growing databases of rat polymorphisms, including those of The Rat SNP Consortium. Furthermore, in order to identify potential mutations and/or new polymorphisms, a systematic screening of the proximal promoters $(2500$ bp) will be performed. In order to exhaustively explore genetic variations, it will be essential to combine DHPLC and sequencing (ABI 310/3100 sequencers) screenings
(Methodology section Question 1). DNA from rats in each population group will be used to define the haplotypes in the genes associated with differing expression post-dietary tratemnt. Haplotypes will be inferred using the PHASE software package [97]. Highly efficient genotyping techniques, depending on the selected variant, will be used to genotype the populations (Denaturing High Performance Liquid Chromatography (DHPLC), Allele Specific Oligonucleoprobe (ASO), SNaPshot ${ }^{\mathrm{TM}}$ Multiplex System).

Question 3: What are the functional consequences of gene variations on the rate of glucose delivery to the cells, the rate of glucose transport and the rate that glucose is phosphorylated within these same cells?

Aim: Determination of glucose delivery to cell membrane, glucose transport across cell membranes and glucose phosphorylation.

Measurement of interstitial glucose is relevant as it is the substrate for glucose transport. This will be performed by microdialysis as previously described [98-100]. Measurement of intracellular glucose will be predictive of the efficiency of glucose transport across cell membranes. This can be done by radioactive glucose analogues that are either not transported or not phosphorylated to calculate glucose concentration localized to each side of the membrane [101-105]. To assess perturbations in glucose phosphorylation, measuring the hexokinase enzyme activity will be performed in kidney, liver and brain tissues of Dahl rats. This will be done as previously described [106,107].

\section{Anticipated results}

On high salt diet, IRS-1 and/or -2 mRNA and protein levels will be diminished in Dahl S versus $\mathrm{R}$ rats (figure 7). No changes are expected in IRS-1 and/or - 2 mRNA and protein levels in Dahl S rats on normal salt diet, or in Dahl $\mathrm{R}$ rats on any of the dietary treatments (low, normal and high salt diet). On low salt diet, IRS-1 and/or -2 mRNA and protein levels in Dahl S rats might not change or on the contrary they might increase because of the reduced levels of sodium acting on the salt-response element in the promoter region of IRS-1 and/or -2. It is postulated in the current hypothesis that this sodium-binding sequence will be a salt-responsive element that will possess an inhibitory effect on IRS-1 and/or -2. The less salt the greater the IRS-1 and/or - 2 mRNA and protein levels. Serine phosphorylation is expected to be enhanced in Dahl S versus $\mathrm{R}$ rats, possibly by the higher insulin levels in Dahl $S$ rats.

On the other hand, variants in the genes encoding the GLUT proteins in Dahl S rats, combined with high salt 


\section{IRS-1 \& IRS-2 and Insulin Resistance}

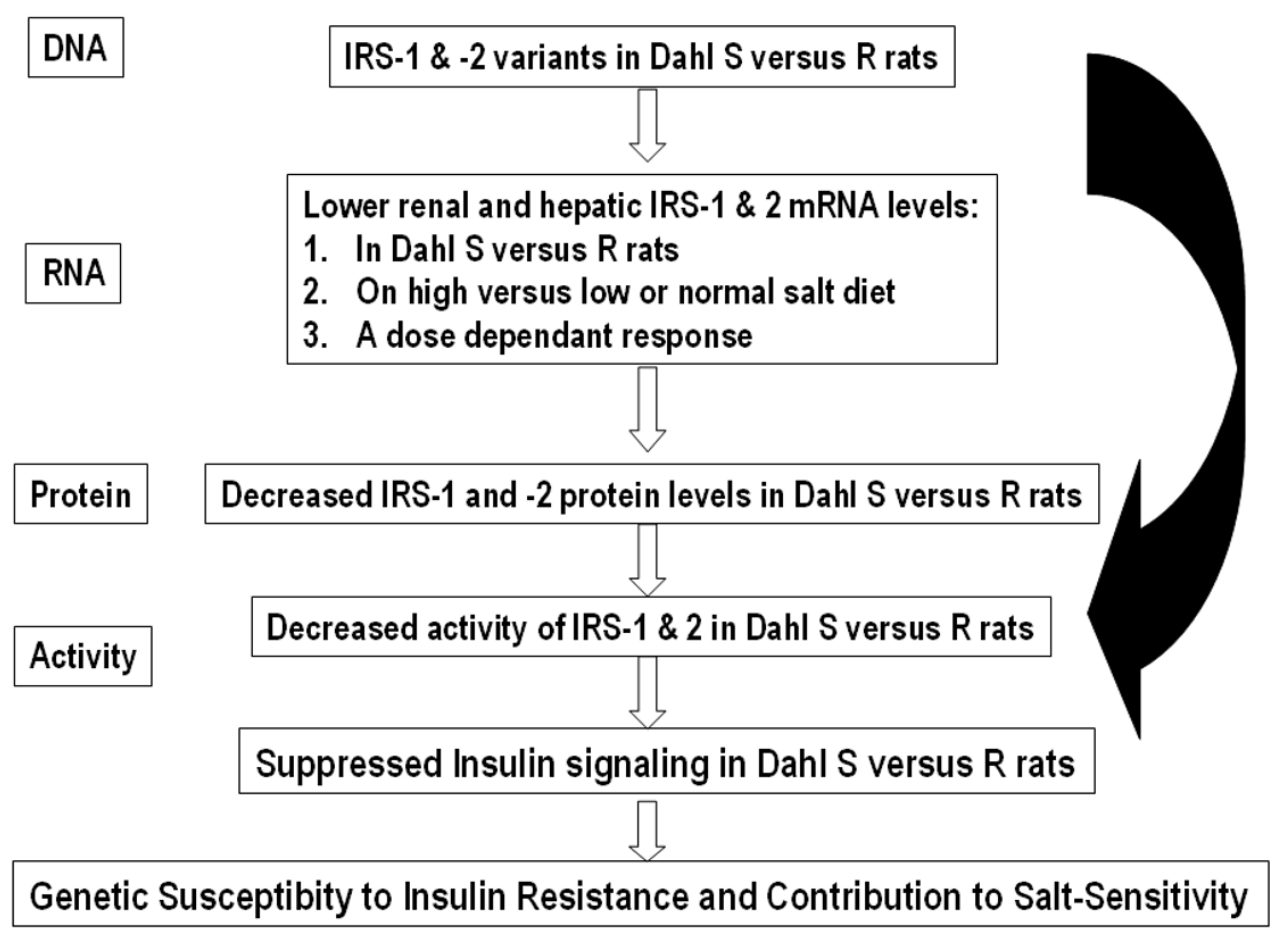

Figure 7

Anticipated Results. Summary of Expected Results in the Proposed Studies: On high salt diet, IRS-I and/or -2 mRNA and protein levels will be diminished in Dahl S versus R rats. No changes are anticipated in IRS-I and/or -2 mRNA and protein levels in Dahl S rats on normal salt diet, or in Dahl R rats on any of the dietary treatments (low, normal and high salt diet). On low salt diet, IRS-I and/or -2 mRNA and protein levels in Dahl S rats might not change or on the contrary they might increase because of the reduced levels of sodium acting on the salt-response element in the promoter region of IRS-I and/or -2 . It is postulated in the present hypothesis that this salt-responsive element possesses an inhibitory effect on IRS-I and/or -2 . The less salt the greater the IRS-I and/or -2 mRNA and protein levels. Serine phosphorylation is expected to be enhanced in Dahl $S$ versus $R$ rats, possibly by the higher insulin levels in Dahl $S$ rats.

will decrease the activity of GLUT proteins and decrease glucose transport in Dahl S rats (figure 8).

\section{Perspectives}

The present hypothesis together with the proposed experimental approach to test it will provide the first comprehensive evaluation of the sequence differences as well as serine phosphorylation patterns of genes along the insulin signaling pathway (IRS-1 and -2 genes and GLUTs) in Dahl S and R rats, and the first comprehensive assessment of the impact of any identified variant (s) on their activity, mRNA and protein levels in Dahl S and R rats. It will also be the first study using microarrays to identify which genes along the inflammatory pathway in Dahl S versus $\mathrm{R}$ rats show differing expression profiles pre and 4-weeks post salt overload, and if successful it will be the first to identify whether or not combined genetic differences along the insulin signaling and inflammatory pathways account for the variance in response to salt intake in or between Dahl-rat groups. Genetic factors contributing to high salt-induced insulin resistance in salt-sensitive Dahl rats will be identified, and the synergistic impact of salt diet will be described. Upon completion of the proposed research project, a sub-set of SNPs in genes encoding the IRS-1, IRS-2, glucose transporters, pro- and anti-inflammatory genes will be identified in Dahl $\mathrm{S}$ rats that might likely influence their susceptibility to insulin resistance and salt-sensitive hypertension.

\section{Competing interests}

The author declares no competing interests. 


\section{Variants in Glucose Transporter Genes}

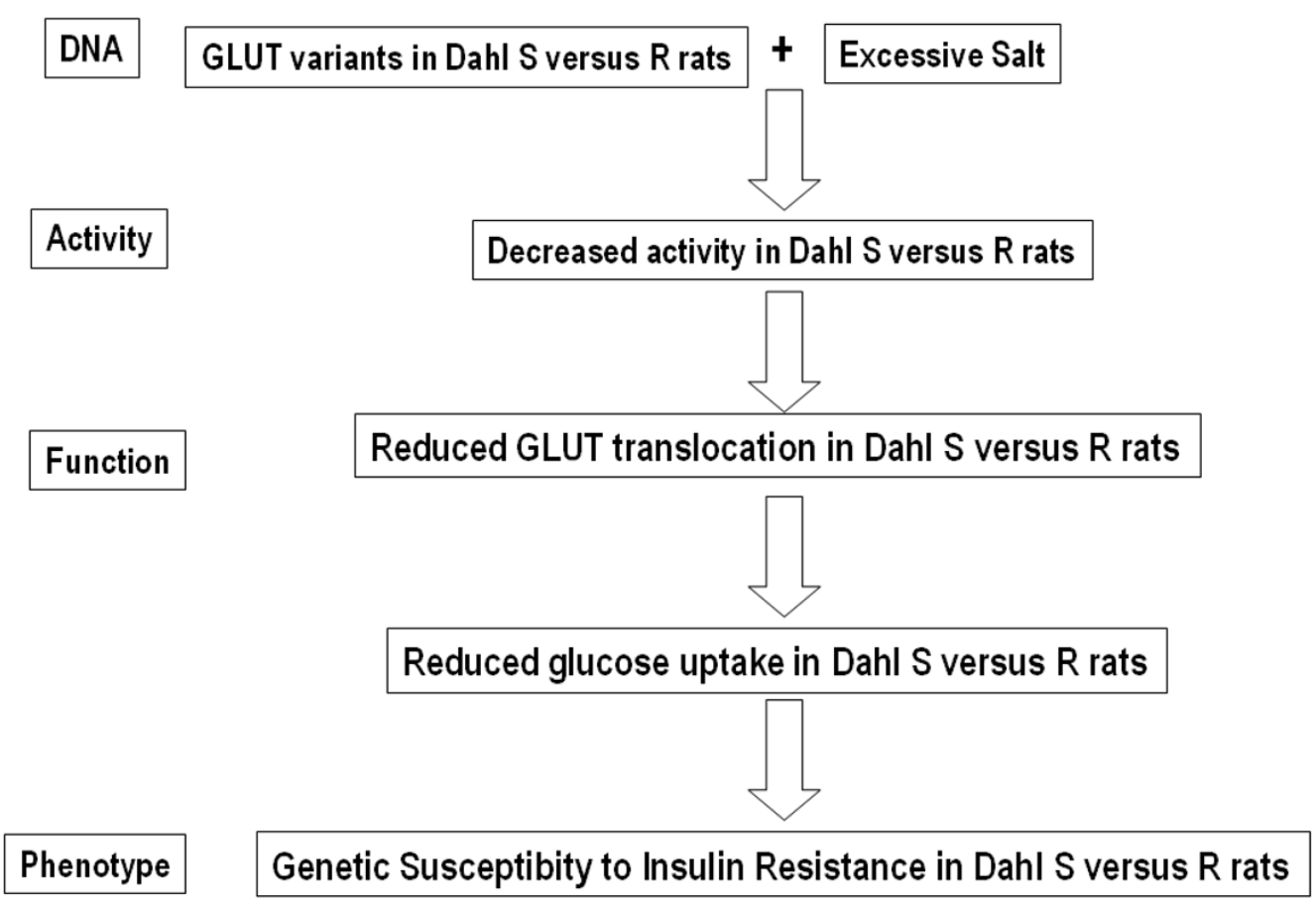

Figure 8

Anticipated Results. Summary of Expected Results in the Proposed Studies: Variants in the genes encoding the GLUT proteins in Dahl S rats, combined with high salt will decrease the activity of GLUT proteins and decrease glucose transport in Dahl $S$ rats.

\section{Authors' contributions}

The author has conceived the hypothesis, and wrote the manuscript.

\section{Acknowledgements}

The author would like to thank Dr. Fady Shehata (Msc. McGill University, Montreal, Canada) for expert assistance in reviewing the manuscript.

\section{References}

I. DeFronzo RA, Ferrannini E: Insulin resistance: A multifaceted syndrome responsible for NIDDM, obesity, hypertension, dyslipidemia and atherosclerotic cardiovascular disease. Diabetes Care 1991, 14(3): 173-194.

2. Reaven G: Role of insulin resistance in human disease. Diabetes 1988, 37:1595.

3. Reaven G: Insulin Resistance, Hypertension, and Coronary Heart Disease. J Clin Hypertens 2003, 5:269.

4. Sievenpiper JL, Jenkins AL, Whitham DL, Vuksan V: Insulin resistance: concepts, controversies, and the role of nutrition. Can J Diet Pract Res 2002, Spring 63(I):20-32.

5. Shehata M: Genetic and dietary salt contributors to insulinresistance in Dahl salt-sensitive (S) rats. Cardiovasc Diabetol 2008, 7:7.

6. Ceriello A, Motz E: Is oxidative stress the pathogenic mechanism underlying insulin resistance, diabetes, and cardiovas- cular disease? The common soil hypothesis revisited. Arterioscler Thromb Vasc Biol 2004, 24:816-823.

7. Hu FB, Stampfer MJ: Is type 2 diabetes mellitus a vascular condition? Arterioscler Thromb Vasc Biol 2003, 23:1715-1716.

8. Roebuck KA: Oxidant stress regulation of IL-8 and ICAM-I gene expression: differential activation and binding of the transcription factors AP-I and NF-kappaB (Review). Int J Mol Med 1999, 4(3):223-230.

9. Manning RD Jr, Meng S, Tian N: Renal and vascular oxidative stress and salt-sensitivity of arterial pressure. Acta Physiol Scand 2003, 179(3):243-250.

10. Matsui H, Shimosawa T, Uetake Y, Wang H, Ogura S, Kaneko T, Liu J, Ando K, Fujita T: Protective effect of potassium against the hypertensive cardiac dysfunction: association with reactive oxygen species reduction. Hypertension 2006, 48(2):225-23I.

II. Dobrian AD, Schriver SD, Lynch T, Prewitt RL: Effect of salt on hypertension and oxidative stress in a rat model of dietinduced obesity. Am J Physiol Renal Physiol 2003, 285(4):F6I9-28.

12. Taylor NE, Glocka P, Liang M, Cowley AWJ: NADPH oxidase in the renal medulla causes oxidative stress and contributes to salt-sensitive hypertension in Dahl S Rats. Hypertension 2006, 47:692.

13. Reddy SY, Leclerc F, Karplus M: DNA polymorphism: a comparison of force fields for nucleic acids. Biophys J 2003, 84(3): $142 \mid-1449$.

14. Zinchenko AA, Yoshikawa $\mathrm{K}: \mathbf{N a}+$ shows a markedly higher potential than $\mathrm{K}+$ in DNA compaction in a crowded environment. Biophys J 2005, 88:4| |8-4I23. 
15. St Lezin E, Simonet L, Pravenec M, Kurtz TW: Hypertensive strains and normotensive 'control' strains. How closely are they related? Hypertension 1992, 19:419-424.

16. Reaven GM, Twersky J, Chang H: Abnormalities of carbohydrate and lipid metabolism in Dahl rats. Hypertension 1991, 18:630-635.

17. Buchanan TA, Sipos GF, Gadalah S, Yip KP, Marsh DJ, Hsueh W, Bergman $\mathrm{RN}$ : Glucose tolerance and insulin action in rats with renovascular hypertension. Hypertension 199I, 18(3):341-347.

18. Tomiyama $H$, Kushiro $T$, Abeta $H$, Kurumatani $H$, Taguchi $H$, Kuga $N$, Saito F, Kobayashi F, Otsuka Y, Kanmatsuse K: Blood pressure response to hyperinsulinemia in salt-sensitive and salt-resistant rats. Hypertension 1992, 20(5):596-600.

19. Ogihara T, Asano T, Ando K, Sakoda H, Anai M, Shojima N, Ono H, Onishi Y, Fujishiro M, Abe M, Fukushima Y, Kikuchi M, Fujita T: Highsalt diet enhances insulin signaling and induces insulin resistance in Dahl salt-sensitive rats. Hypertension 2002, 40(I):83-89.

20. Sechi LA, Griffin CA, Zingaro L, Catena C, De Carli S, Schambelan M, Bartoli E: Glucose metabolism and insulin receptor binding and mRNA levels in tissues of Dahl hypertensive rats. $\mathrm{Am} \mathrm{J}$ Hypertens 1997, 10(II): 1223-1230.

21. Garvey WT, Birnbaum MJ: Cellular insulin action and insulin resistance. Baillieres Clin Endocrinol Metab 1993, 7:785-873.

22. Cheatham B, Kahn CR: Insulin action and the insulin signaling network. Endocr Rev 1995, 16: I I7-142.

23. Sun XJ, Rothenberg P, Kahn CR, Backer JM, Araki E, Wilden PA, Cahill DA, Goldstein BJ, White MF: Structure of the insulin receptor substrate IRS-I defines a unique signal transduction protein. Nature 1991, 352:73-77.

24. Sun XJ, Wang LM, Zhang Y, Yenush L, Myers MG Jr, Glasheen E, Lane WS, Pierce JH, White MF: Role of IRS-2 in insulin and cytokine signaling. Nature 1995, 377:173-177.

25. Laakso M, Malkki M, Kekalainen P, Kuusisto J, Deeb SS: Insulin receptor substrate-I variants in non-insulin-dependent diabetes. J Clin Invest 1994, 94: I |4 I- I I46.

26. Lavan BE, Fantin VR, Chang ET, Lane WS, Keller SR, Lienhard GE: A novel $160-\mathrm{kDa}$ phosphotyrosine protein in insulin-treated embryonic kidney cells is a new member of the insulin receptor substrate family. J Biol Chem 1997, 272(34):2। 403-2I 407.

27. Paz K, Voliovitch H, Hadari YR, Roberts CT Jr, LeRoith D, Zick Y: Interaction between the insulin receptor and its downstream effectors. Use of individually expressed receptor domains for structure/function analysis. J Biol Chem 1996, 27 I ( I 2):6998-7003.

28. Almind K, Inoue G, Pedersen O, Kahn CR: A common amino acid polymorphism in insulin receptor substrate-I causes impaired insulin signaling. Evidence from transfection studies. J Clin Invest 1996, 97(I I):2569-2575

29. Berger D, Barroso I, Soos M, Yeo G, Schafer AJ, O'Rahilly S, Whitehead JP: Genetic variants of insulin receptor substrate-I (IRSI) in syndromes of severe insulin resistance. Functional analysis of Ala5 I3Pro and GlyI I 58Glu IRS-I. Diabet Med 2002, I 9 ( I 0):804-809.

30. Celi FS, Negri C, Tanner K, Raben N, De Pablo F, Rovira A, Pallardo LF, Martin-Vaquero P, Stern MP, Mitchell BD, Shuldiner AR: Molecular scanning for mutations in the insulin receptor substrateI (IRS-I) gene in Mexican Americans with Type 2 diabetes mellitus. Diabetes Metab Res Rev 2000, 16(5):370-377.

31. Clausen JO, Hansen T, Bjorbaek C, Echwald SM, Urhammer SA, Rasmussen S, Andersen CB, Hansen L, Almind K, Winther K: Insulin resistance: interactions between obesity and a common variant of insulin receptor substrate-I. Lancet 1995 , 346(8972):397-402

32. Imai $Y$, Fusco A, Suzuki $Y$, Lesniak MA, D'Alfonso R, Sesti G, Bertoli A, Lauro R, Accili D, Taylor SI: Variant sequences of insulin receptor substrate- $I$ in patients with noninsulin-dependent diabetes mellitus. J Clin Endocrinol Metab 1994, 79(6):1655-1658.

33. Le Fur S, Le Stunff C, Bougneres P: Increased insulin resistance in obese children who have both 972 IRS-I and I057 IRS-2 polymorphisms. Diabetes 2002, 5 I (Suppl 3):S304-7.

34. Lei HH, Coresh J, Shuldiner AR, Boerwinkle E, Brancati FL: Variants of the insulin receptor substrate- $I$ and fatty acid binding protein 2 genes and the risk of type 2 diabetes, obesity, and hyperinsulinemia in African-Americans: the Atherosclerosis Risk in Communities Study. Diabetes 1999, 48(9): 1868-1872.
35. Mammarella S, Creati B, Esposito DL, Arcuri P, Della Loggia F, Capani F, Mariani-Costantini R, Caramia FG, Battista P, Cama A: Novel allele of the insulin receptor substrate-I bearing two nonconservative amino acid substitutions in a patient with noninsulin-dependent diabetes mellitus. Mutations in brief no. 130. Online. Hum Mutat 1998, I I(5):4I I.

36. 't Hart LM, Nijpels G, Dekker JM, Maassen JA, Heine RJ, van Haeften TW: Variations in insulin secretion in carriers of gene variants in IRS-I and -2. Diabetes 2002, 5 I (3):884-887.

37. Sesti G, Federici M, Hribal ML, Lauro D, Sbraccia P, Lauro R: Defects of the insulin receptor substrate (IRS) system in human metabolic disorders. FASEB J 200 I, 15( I 2):2099-2 III

38. Sun XJ, Crimmins DL, Myers MG Jr, Miralpeix M, White MF: Pleiotropic insulin signals are engaged by multisite phosphorylation of IRS-I. Mol Cell Biol I993, I3(I 2):74|8-7428.

39. Qiao LY, Zhande R, Jetton TL, Zhou G, Sun XJ: In vivo phosphorylation of insulin receptor substrate $I$ at serine 789 by a novel serine kinase in insulin-resistant rodents. J Biol Chem 2002, 277:26530-26539.

40. Draznin B: Molecular mechanisms of insulin resistance: serine phosphorylation of insulin receptor substrate-I and increased expression of p85alpha: the two sides of a coin. Diabetes 2006, 55(8):2392-2397.

4I. Greene MW, Sakaue H, Wang L, Alessi DR, Roth RA: Modulation of insulin-stimulated degradation of human insulin receptor substrate-I by Serine 3I 2 phosphorylation. J Biol Chem 2003, 278(10):8199-82II.

42. Liu YF, Herschkovitz A, Boura-Halfon S, Ronen D, Paz K, Leroith D, Zick Y: Serine phosphorylation proximal to its phosphotyrosine binding domain inhibits insulin receptor substrate I function and promotes insulin resistance. Mol Cell Biol 2004, 24(2I):9668-968I

43. Paz K, Hemi R, LeRoith D, Karasik A, Elhanany E, Kanety H, Zick Y: A molecular basis for insulin resistance. Elevated serine/ threonine phosphorylation of IRS-I and IRS-2 inhibits their binding to the juxtamembrane region of the insulin receptor and impairs their ability to undergo insulin-induced tyrosine phosphorylation. J Biol Chem 1997, 272(47):299| I-29918.

44. Asano $\mathrm{T}$, Ogihara $\mathrm{T}$, Katagiri $\mathrm{H}$, Sakoda $\mathrm{H}$, Ono $\mathrm{H}$, Fujishiro $M$, Anai M, Kurihara $\mathrm{H}$, Uchijima $\mathrm{Y}$ : Glucose transporter and $\mathbf{N a + / g l u - ~}$ cose cotransporter as molecular targets of anti-diabetic drugs. Curr Med Chem 2004, I I(20):27I7.

45. Ruiz-Opazo N, Cloix JF, Melis MG, Xiang XH, Herrera VL: Characterization of a sodium-response transcriptional mechanism. Hypertension 1997, 30(2 Pt I): I9|-198.

46. Kitiyakara C, Chabrashvili T, Chen Y, Blau J, Karber A, Aslam S, Welch W], Wilcox CS: Salt intake, oxidative stress, and renal expression of NADPH oxidase and superoxide dismutase. Am Soc Nephrol 2003, I 4(I I):2775-2782.

47. Hansen LL, Ikeda Y, Olsen GS, Busch AK, Mosthaf L: Insulin signaling is inhibited by micromolar concentrations of $\mathrm{H}(2) \mathrm{O}(2)$. Evidence for a role of $\mathrm{H(2)O(2)}$ in tumor necrosis factor alpha-mediated insulin resistance. I Biol Chem 1999, 274:25078-25084.

48. Rudich A, Tirosh A, Potashnik R, Hemi R, Kanety H, Bashan N: Prolonged oxidative stress impairs insulin-induced GLUT4 translocation in 3T3-LI adipocytes. Diabetes 1998 47(10): I562-1569.

49. Tirosh A, Potashnik R, Bashan N, Rudich A: Oxidative stress disrupts insulin-induced cellular redistribution of insulin receptor substrate-I and phosphatidylinositol 3-kinase in 3T3-LI adipocytes. A putative cellular mechanism for impaired protein kinase B activation and GLUT4 translocation. J Biol Chem 1999, 274(I 5): 10595-10602.

50. Talior I, Yarkoni M, Bashan N, Eldar-Finkelman H: Increased glucose uptake promotes oxidative stress and PKC-delta activation in adipocytes of obese, insulin-resistant mice. Am J Physiol Endocrinol Metab 2003, 285(2):E295-302.

51. Fujita M, Ando K, Nagae A, Fujita T: Sympathoexcitation by oxidative stress in the brain mediates arterial pressure elevation in salt-sensitive hypertension. Hypertension 2007, 50(2):360-367.

52. Gu JW, Tian N, Shparago M, Tan W, Bailey AP, Manning RD Jr: Renal NF-kappaB activation and TNF-alpha upregulation correlate with salt-sensitive hypertension in Dahl salt-sensitive rats. Am J Physiol Regul Integr Comp Physiol 2006, 29 I (6):RI8I7-24. 
53. Hamaguchi A, Kim S, Izumi $\mathrm{Y}$, Iwao $\mathrm{H}$ : Chronic activation of glomerular mitogen-activated protein kinases in Dahl saltsensitive rats. J Am Soc Nephrol 2000, I I (I):39-46.

54. Kanety H, Feinstein R, Papa MZ, Hemi R, Karasik A: Tumor necrosis factor alpha-induced phosphorylation of insulin receptor substrate-I (IRS-I). Possible mechanism for suppression of insulin-stimulated tyrosine phosphorylation of IRS-I. J Biol Chem 1995, 270(40):23780-23784.

55. Paz K, Hemi R, LeRoith D, Karasik A, Elhanany E, Kanety H, Zick Y: A molecular basis for insulin resistance. Elevated serinel threonine phosphorylation of IRS-I and IRS-2 inhibits their binding to the juxtamembrane region of the insulin receptor and impairs their ability to undergo insulin-induced tyrosine phosphorylation. J Biol Chem 1997, 272(47):299| I-299/8.

56. Feinstein R, Kanety H, Papa MZ, Lunenfeld B, Karasik A: Tumor necrosis factor-alpha suppresses insulin-induced tyrosine phosphorylation of insulin receptor and its substrates. J Biol Chem 1993, 268(35):26055-26058.

57. Aguirre V, Uchida T, Yenush L, Davis R, White MF: The c-Jun NH(2)-terminal kinase promotes insulin resistance during association with insulin receptor substrate-I and phosphorylation of Ser(307). J Biol Chem 2000, 275( ( 2):9047-9054.

58. Venkatesha RT, Ahamed J, Nuesch C, Zaidi AK, Ali H: Platelet-activating factor-induced chemokine gene expression requires NF-kappaB activation and $\mathrm{Ca} 2+/$ calcineurin signaling pathways. Inhibition by receptor phosphorylation and beta-arrestin recruitment. J Biol Chem 2004, 279(43):44606-446I2.

59. Kim JK, Kim YJ, Fillmore J], Chen Y, Moore I, Lee J, Yuan M, Li ZW, Karin M, Perret P, Shoelson SE, Shulman Gl: Prevention of fatinduced insulin resistance by salicylate. J Clin Invest 200I, 108(3):437-446.

60. Yuan M, Konstantopoulos N, Lee J, Hansen L, Li ZW, Karin M, Shoelson SE: Reversal of obesity- and diet-induced insulin resistance with salicylates or targeted disruption of Ikkbeta. Science 200I, 293(5535): 1673-1677.

61. Wasserman DH, Ayala JE: Interaction of physiological mechanisms in control of muscle glucose uptake. Clin Exp Pharmacol Physiol 2005, 32(4):319-323.

62. Manchester J, Kong X, Nerbonne J, Lowry OH, Lawrence JC Jr: Glucose transport and phosphorylation in single cardiac myocytes: rate-limiting steps in glucose metabolism. Am J Physiol 1994, 266(Pt I):E326-33.

63. Furler SM, Jenkins $A B$, Storlien $L H, K$ raegen EW: In vivo location of the rate-limiting step of hexose uptake in muscle and brain tissue of rats. Am J Physiol I99I, 26 I (3 Pt I):E337-47.

64. Kubo K, Foley JE: Rate-limiting steps for insulin-mediated glucose uptake into perfused rat hindlimb. Am J Physiol 1986, 250(I Pt I): EI00-2.

65. Saavedra JM, Del Carmine R, McCarty R, Guicheney P, Weise V, Iwai $\mathrm{J}$ : Increased adrenal catecholamines in salt-sensitive genetically hypertensive Dahl rats. Am J Physiol 1983, 245(5 Pt I):H762-6

66. Rizza RA, Cryer PE, Haymond MW, Gerich JE: Adrenergic mechanisms of catecholamine action on glucose homeostasis in man. Metabolism 1980, 29(II SuppI I): I I55-II63.

67. Rizza RA, Cryer PE, Haymond MW, Gerich JE: Adrenergic mechanisms for the effects of epinephrine on glucose production and clearance in man. J Clin Invest 1980, 65(3):682-689.

68. Chiasson JL, Shikama H, Chu DT, Exton JH: Inhibitory effect of epinephrine on insulin-stimulated glucose uptake by rat skeletal muscle. J Clin Invest 198I, 68(3):706-713.

69. James DE, Burleigh KM, Kraegen EW: In vivo glucose metabolism in individual tissues of the rat. Interaction between epinephrine and insulin. J Biol Chem 1986, 26 I ( 1 4):6366-6374.

70. Jensen J, Aslesen R, Ivy JL, Brors O: Role of glycogen concentration and epinephrine on glucose uptake in rat epitrochlearis muscle. Am J Physiol 1997, 272(4 Pt I):E649-55.

71. Jensen J, Dahl HA: Adrenaline stimulated glycogen breakdown in rat epitrochlearis muscles: fibre type specificity and relation to phosphorylase transformation. Biochem Mol Biol Int 1995, 35(1): 145-154.

72. Richter EA: Influence of the sympatho-adrenal system on some metabolic and hormonal responses to exercise in the rat with special reference to the effect on glycogenolysis in skeletal muscle. Acta Physiol Scand Suppl 1984, 528: |-42.
73. Hansen PA, Gulve EA, Holloszy JO: Suitability of 2-deoxyglucose for in vitro measurement of glucose transport activity in skeletal muscle. J Appl Physiol 1994, 76(2):979-985.

74. Lueck JD, Fromm HJ: Kinetics, mechanism, and regulation of rat skeletal muscle hexokinase. I Biol Chem 1974, 249(5): | $34 \mid-1347$.

75. Challiss RA, Lozeman FJ, Leighton B, Newsholme EA: Effects of the beta-adrenoceptor agonist isoprenaline on insulin-sensitivity in soleus muscle of the rat. Biochem J 1986, 233(2):377-38I.

76. Lee AD, Hansen PA, Schluter J, Gulve EA, Gao J, Holloszy JO: Effects of epinephrine on insulin-stimulated glucose uptake and GLUT-4 phosphorylation in muscle. Am J Physiol I 997, 273(3 Pt I):C1082-7.

77. Young DA, Wallberg-Henriksson H, Cranshaw J, Chen M, Holloszy JO: Effect of catecholamines on glucose uptake and glycogenolysis in rat skeletal muscle. Am J Physiol 1985, 248(5 Pt I):C406-9.

78. Wilson JE: Brain hexokinase. A proposed relation between soluble-particulate distribution and activity in vivo. J Biol Chem 1968, 243(13):3640-3647.

79. Sechi LA: Mechanisms of insulin resistance in rat models of hypertension and their relationships with salt sensitivity. J Hypertens 1999, 17(9):1229-1237.

80. Sechi LA, Bartoli E: Mechanisms of insulin resistance leading to hypertension: what we can learn from experimental models. J Investig Med 1997, 45(5):238-25|.

8I. Shehata MF, Leenen FH, Tesson F: Sequence analysis of coding and 3 ' and ' 5 ' flanking regions of the epithelial sodium channel alpha, beta, and gamma genes in Dahl S versus $\mathbf{R}$ rats. $B M C$ Genet 2007, 8:35.

82. Shehata MF, Leenen FHH, Tesson F: Polymorphisms in 5'UTR of $\mathrm{ENaC} \alpha, \beta$ and $\gamma$ genes in Dahl and Wistar rats. FASEB 2006, 20:A3I0-A3II.

83. Shehata MF, Tesson F, Leenen FH: Are Genetic Variations in the Coding Sequence of ENaC Alpha, Beta and/or Gamma Subunits Associated with Salt Sensitive Hypertension in Dahl Rats? Can / Cardiology 2005, 2 1: I35C.

84. Shehata MF, Tesson F, Leenen FH: Are Genetic Variations in the Coding Sequence of ENaC Alpha, Beta and/or Gamma Subunits Associated with Salt Sensitive Hypertension in Dahl Rats? Second Annual Research Forum for Young Investigators in Circulatory and Respiratory Health 2005.

85. Ellis LA, Taylor CF, Taylor GR: A comparison of fluorescent SSCP and denaturing HPLC for high throughput mutation scanning. Hum Mutat 2000, 15(6):556-564.

86. Eshleman SH, Crutcher G, Petrauskene O, Kunstman K, Cunningham SP, Trevino C, Davis C, Kennedy J, Fairman J, Foley B, Kop J: Sensitivity and specificity of the ViroSeq human immunodeficiency virus type I (HIV-I) genotyping system for detection of HIV-I drug resistance mutations by use of an ABI PRISM 3100 genetic analyzer. / Clin Microbiol 2005, 43(2):8I3-8I7.

87. Shehata M, Shehata M, Shehata F, Pater A: Apoptosis effects of Xrel3 c-Rel/Nuclear Factor-kappa B homolog in human cervical cancer cells. Cell Biol Int 2005, 29(6):429-440.

88. Shehata M, Shehata M, Shehata F, Pater A: Dual apoptotic effect of Xrel3 c-Rel/NF-kappaB homolog in human cervical cancer cells. Cell Biol Int 2004, 28( I 2):895-904.

89. Shehata MF: Rel/Nuclear factor-kappa B apoptosis pathways in human cervical cancer cells. Cancer Cell Int 2005, 5(I): I0.

90. Shehata MF, Tesson F, Leenen FH: Polymorphisms in 5'UTR of ENaC alpha, beta and gamma genes in Dahl and Wstar rats. Third Annual Research Forum for Young Investigators in Circulatory and Respiratory Health 2006.

91. Rojas FA, Hirata AE, Saad MJ: Regulation of IRS-2 tyrosine phosphorylation in fasting and diabetes. Mol Cell Endocrinol 200I, 183(1-2):63-69.

92. Valverde $A M$, Benito $M$, Lorenzo $M$ : The brown adipose cell: a model for understanding the molecular mechanisms of insulin resistance. Acta Physiol Scand 2005, I 83(I):59-73.

93. Valverde AM, Benito M: The brown adipose cell: a unique model for understanding the molecular mechanism of insulin resistance. Mini Rev Med Chem 2005, 5(3):269-278.

94. Cengel KA, Freund GG: JAKI-dependent phosphorylation of insulin receptor substrate-I (IRS-I) is inhibited by IRS-I serine phosphorylation. J Biol Chem 1999, 274(39):27969-27974. 
95. Sechi LA, Griffin CA, Zingaro L, Valentin JP, Bartoli E, Schambelan M: Effects of angiotensin II on insulin receptor binding and mRNA levels in normal and diabetic rats. Diabetologia 1997 40(7):770-777.

96. Risch N, Merikangas K: The future of genetic studies of complex human diseases. Science 1996, 273:1516-1517.

97. Stephens M, Smith NJ, Donnelly P: A new statistical method for haplotype reconstruction from population data. Am J Hum Genet 200I, 68(4):978-989.

98. Holmang A, Mimura K, Bjorntorp P, Lonnroth P: Interstitial muscle insulin and glucose levels in normal and insulin-resistant Zucker rats. Diabetes 1997, 46(I I): I799-1804.

99. Holmang A, Muller M, Andersson OK, Lonnroth P: Minimal influence of blood flow on interstitial glucose and lactate-normal and insulin-resistant muscle. Am J Physiol 1998, 274(3 Pt I):E446-52.

100. Muller M, Holmang A, Andersson OK, Eichler HG, Lonnroth P. Measurement of interstitial muscle glucose and lactate concentrations during an oral glucose tolerance test. Am J Physiol 1996, 27 I (6 Pt I): El 003-7.

10I. Halseth $A E$, Bracy DP, Wasserman DH: Functional limitations to glucose uptake in muscles comprised of different fiber types. Am J Physiol Endocrinol Metab 200I, 280(6):E994-9.

102. Halseth $A E$, Bracy DP, Wasserman DH: Limitations to basal and insulin-stimulated skeletal muscle glucose uptake in the high-fat-fed rat. Am J Physiol Endocrinol Metab 2000 279(5): EI064-7I.

103. Halseth AE, Bracy DP, Wasserman DH: Limitations to exerciseand maximal insulin-stimulated muscle glucose uptake. Appl Physiol 1998, 85(6):2305-23।3

104. Petersen HA, Fueger PT, Bracy DP, Wasserman DH, Halseth AE: Fiber type-specific determinants of Vmax for insulin-stimulated muscle glucose uptake in vivo. Am J Physiol Endocrinol Metab 2003, 284(3):E54I-8.

105. O'Doherty RM, Halseth AE, Granner DK, Bracy DP, Wasserman DH: Analysis of insulin-stimulated skeletal muscle glucose uptake in conscious rat using isotopic glucose analogs. Am J Physiol 1998, 274(2 Pt I):E287-96.

106. Fiorani M, De Sanctis R, Saltarelli R, Stocchi V: Hexokinase inactivation induced by ascorbic acid/Fe(II) in rabbit erythrocytes is independent of glutathione-reductive processes and appears to be mediated by dehydroascorbic acid. Arch Biochem Biophys 1997, 342(2):191-196.

107. Fiorani M, De Sanctis R, Scarlatti F, Vallorani L, De Bellis R, Serafini G, Bianchi M, Stocchi V: Dehydroascorbic acid irreversibly inhibits hexokinase activity. Mol Cell Biochem 2000, 209(I-2): I45-I53.

108. Wilden PA, Siddle K, Haring E, Backer JM, White MF, Kahn CR: The role of insulin receptor kinase domain autophosphorylation in receptor-mediated activities. Analysis with insulin and anti-receptor antibodies. J Biol Chem 1992 267(19): 137|9-13727.

109. Kanai F, Ito K, Todaka M, Hayashi H, Kamohara S, Ishii K, Okada T, Hazeki O, Ui M, Ebina Y: Insulin-stimulated GLUT4 translocation is relevant to the phosphorylation of IRS-I and the activity of PI3-kinase. Biochem Biophys Res Commun 1993, 195(2):762-768.

II0. Moran A, Steffen LM, Jacobs DR Jr, Steinberger J, Pankow JS, Hong CP, Tracy RP, Sinaiko AR: Relation of C-reactive protein to insulin resistance and cardiovascular risk factors in youth. Diabetes Care 2005, 28(7): 1763-1768.

III. Curran JE, Jowett JB, Elliott KS, Gao Y, Gluschenko K, Wang J, Abe Azim DM, Cai G, Mahaney MC, Comuzzie AG, Dyer TD, Walder KR, Zimmet P, MacCluer JW, Collier GR, Kissebah AH, Blangero J: Genetic variation in selenoprotein $\mathbf{S}$ influences inflammatory response. Nat Genet 2005, 37( I I): | 234- I24I.

112. Onengut-Gumuscu S, Buckner JH, Concannon P: A haplotypebased analysis of the PTPN22 locus in type I diabetes. Diabetes 2006, 55(I 0):2883-2889.

1 13. Onengut-Gumuscu S, Ewens KG, Spielman RS, Concannon P: A functional polymorphism $(1858 \mathrm{C} / \mathrm{T})$ in the PTPN22 gene is linked and associated with type I diabetes in multiplex families. Genes Immun 2004, 5(8):678-680.

II4. Zheng W, She JX: Genetic association between a lymphoid tyrosine phosphatase (PTPN22) and type I diabetes. Diabetes 2005, 54(3):906-908.
115. Muller S, Martin S, Koenig W, Hanifi-Moghaddam P, Rathmann W, Haastert B, Giani G, Illig T, Thorand B, Kolb H: Impaired glucose tolerance is associated with increased serum concentrations of interleukin 6 and co-regulated acute-phase proteins but not TNF-alpha or its receptors. Diabetologia 2002, 45:805-8I2.

II6. Busquets S, Figueras M, Almendro V, Lopez-Soriano FJ, Argiles JM: Interleukin- 15 increases glucose uptake in skeletal muscle. An antidiabetogenic effect of the cytokine. Biochim Biophys Acto 2006, I760(II):1613-1617.

II7. Zhang YF, Yang YS, Hong J, Gu WQ, Shen CF, Xu M, Du PF, Li XY, Ning G: Elevated serum levels of interleukin- 18 are associated with insulin resistance in women with polycystic ovary syndrome. Endocrine 2006, 29(3):419-423.

1 18. Fischer CP, Perstrup LB, Berntsen A, Eskildsen P, Pedersen BK: Elevated plasma interleukin- 18 is a marker of insulin-resistance in type 2 diabetic and non-diabetic humans. Clin Immunol 2005, II7(2):152-160.

119. Anhe GF, Torrao AS, Nogueira TC, Caperuto LC, Amaral ME, Medina MC, Azevedo-Martins AK, Carpinelli AR, Carvalho CR, Curi R, Boschero AC, Bordin S: ERK3 associates with MAP2 and is involved in glucose-induced insulin secretion. Mol Cell Endocrinol 2006, 25 I (I-2):33-4I.

120. Bouzakri K, Zierath JR: MAP4K4 gene silencing in human skeletal muscle prevents tumor necrosis factor-alpha-induced insulin resistance. J Biol Chem 2007, 282(I I):7783-7789.

121. Tang X, Guilherme A, Chakladar A, Powelka AM, Konda S, Virbasius JV, Nicoloro SM, Straubhaar J, Czech MP: An RNA interferencebased screen identifies MAP4K4/NIK as a negative regulator of PPARgamma, adipogenesis, and insulin-responsive hexose transport. Proc Natl Acad Sci USA 2006, 103:2087-2092.

122. Matter CM, Handschin C: RANTES (regulated on activation, normal $T$ cell expressed and secreted), inflammation, obesity, and the metabolic syndrome. Circulation 2007, I I 5(2):946-948.

123. Weisberg SP, Hunter D, Huber R, Lemieux J, Slaymaker S, Vaddi K, Charo I, Leibel RL, Ferrante AW Jr: CCR2 modulates inflammatory and metabolic effects of high-fat feeding. I Clin Invest 2006, II6(I): II5-124.

124. de Silva E, Stumpf MP: HIV and the CCR5-Delta32 resistance allele. FEMS Microbiol Lett 2004, 24I:I-12.

125. Carnesecchi S, Carpentier JL, Foti M, Szanto I: Insulin-induced vascular endothelial growth factor expression is mediated by the NADPH oxidase NOX3. Exp Cell Res 2006, 3 I 2(17):3413-3424.

126. Mahadev K, Motoshima H, Wu X, Ruddy JM, Arnold RS, Cheng G, Lambeth JD, Goldstein BJ: The NAD(P)H oxidase homolog Nox4 modulates insulin-stimulated generation of $\mathrm{H} 2 \mathrm{O} 2$ and plays an integral role in insulin signal transduction. Mol Cell Biol 2004, 24:1844-1854.

127. Konheim YL, Wolford JK: Association of a promoter variant in the inducible cyclooxygenase-2 gene (PTGS2) with type 2 diabetes mellitus in Pima Indians. Hum Genet 2003, I 13:377-381.

128. Kaaman M, Ryden M, Axelsson T, Nordstrom E, Sicard A, Bouloumie A, Langin D, Arner P, Dahlman I: ALOX5AP expression, but not gene haplotypes, is associated with obesity and insulin resistance. Int J Obes (Lond) 2006, 30:447-452

129. Ohtoshi K, Yamasaki Y, Gorogawa S, Hayaishi-Okano R, Node K, Matsuhisa M, Kajimoto $Y$, Hori M: Association of (-)786T-C mutation of endothelial nitric oxide synthase gene with insulin resistance. Diabetologia 2002, 45(II):|594-160I.

130. Perreault $M$, Marette A: Targeted disruption of inducible nitric oxide synthase protects against obesity-linked insulin resistance in muscle. Nat Med 2001, 7(10): I |38-1 | 43.

13I. Tsuchiyama N, Takamura T, Ando H, Sakurai M, Shimizu A, Kato K, Kurita S, Kaneko S: Possible role of alpha-cell insulin resistance in exaggerated glucagon responses to arginine in type 2 diabetes. Diabetes Care 2007, 30(10):2583-2587.

132. Labonte ED, Kirby RJ, Schildmeyer NM, Cannon AM, Huggins KW, Hui DY: Group IB phospholipase A2-mediated lysophospholipid absorption directly contributes to postprandial hyperglycemia. Diabetes 2006, 55(4):935-941.

133. Ensemble [http://www.ensembl.org] 